\title{
Kabbaldurga charnockites revisited: Incipient growth or anatectic melt?
}

\author{
Samarendra Bhattacharya ${ }^{1^{*}}$, Aswini K. Chaudhary ${ }^{2}$ \\ ${ }^{1}$ Indian Statistical Institute, Kolkata, India; ${ }^{*}$ Corresponding Author: samar.bhattacharya@gmail.com \\ ${ }^{2}$ Indian Institute of Technology, Roorkee, India
}

Received 5 January 2013; revised 8 February 2013; accepted 20 February 2013

\begin{abstract}
A popular hypothesis of in situ transformation of amphibolite facies gneisses to patchy charnockites by $\mathrm{CO}_{2}$ influx from mantle was proposed primarily from the Kabbaldurga quarries in South Karnataka and subsequently reported from several south Indian localities. However, presence of abundant mafic granulite enclaves in Kabbaldurga and its neighborhood and its implications in relation to patchy charnockite genesis were not discussed. In these quarries patchy charnockites occur in various modes and associations. Some of these patches do occupy structural weak zones, such as shear bands and fold noses in the migmatitic gneisses, but many of the patchy charnockite bodies occur as branching veins transecting the gneissic foliation and hence do not account for fluid pathways. Most importantly, charnockitic leucosomes at margins of mafic granulite enclaves and charnockitic veins within some mafic granulite enclaves indicate a close genetic link between them via dehydration partial melting. This is further corroborated by trace element distribution between them. Dehydration partial melting in mafic rocks in a migmatite terrain such as Kabbaldurga, can explain all the different modes of the patchy charnockites as various stages of segregation and mobility relative to deformation. Abundant mafic granulite enclaves and field features suggesting a relatively late origin of the patchy charnockites, are compelling evidence against the notion of a transition zone. Mantle derivation age of the mafic source rocks (protoliths of mafic granulites) at Kabbaldurga at 3.08 $\pm 0.08 \mathrm{Ga}$ with small positive $\varepsilon$ values is virtually identical to the source of the massive charnockite of Karnataka craton at $3.08 \mathrm{Ga}$. This could imply a widespread mafic magmatism in South India around 3.0 Ga.
\end{abstract}

Keywords: Migmatite Zone; Crustal Anatexis; Mafic Magmatism

\section{INTRODUCTION}

Following initial observation by Pichamuthu [1], Kabbaldurga quarries in Southern Karnataka drew worldwide attention in the 1980s and the hypothesis of in situ transformation of amphibolite facies Peninsular gneiss to charnockite aided by $\mathrm{CO}_{2}$ fluid ingress was advocated [2]. Several subsequent publications provided purported lines of evidence pertaining to field structures, petrography and geochemistry to explain the mechanism of in situ transformation [3-7]. Structural weak zones were suggested to define the channel ways for fluid-ingress.

In the 1990s the $\mathrm{CO}_{2}$-influx mechanism for incipient charnockite formation was seriously challenged and Brown [8] pointed out that considerable experimental results were contrary to the views of Peterson and Newton [9], which implied that $\mathrm{CO}_{2}$ should be more soluble than $\mathrm{H}_{2} \mathrm{O}$ at relevant $\mathrm{P}$ and $\mathrm{T}$. Finally, it was conceded that "The free streaming of $\mathrm{CO}_{2}$ through deep crust, as envisioned in [2], may not be a feasible process" [10]. However, fluid inclusion studies from several South Indian localities, except Kabbaldurga, strongly argued to favor the hypothesis of $\mathrm{CO}_{2}$-fluid ingress causing the transformation of amphibolite facies gneiss to incipient charnockite [11-14].

As for gneiss to charnockite transformation, Hansen et al. [5] and Stahle et al. [6] could not provide convincing petrographic and geochemical evidence. Their suggested hornblende and biotite breakdown reactions demand more plagioclase in the charnockites, but Table 2 in Hansen et al. [5] show comparable or even lower modal plagioclase in the charnockites. Hansen et al. [5] and Stahle et al. [6] noted discordant observations, such as $\mathrm{Rb}$ enrichment and depletion respectively. And Friend and Nutman [7] conceded that "For most major and trace elements, consistent enrichment or depletion trends associated with the transition to granulite facies can not be identified with confidence". 
From a structural point of view Naha et al. [15] concluded that "...that charnockites of the Dharwar craton have evolved in at least two distinct phases, separate both in time and in process". Although, isotopic data so far reported [16] could not distinguish the massive charnockites from the patchy charnockites ("incipient"), preexisting deep crustal granulites at Kabbaldurga quarries was indicated as the source of the $\mathrm{CO}_{2}$-fluid, said to be responsible for the gneiss to incipient charnockite transformation [17]. Bhattacharya and Sen [18] had pointed out that "Recognizing earlier granulite facies rocks would have demanded some explanation for the notion of a transition zone". It is unfortunate that this notion of the transition zone still dominates the scientific literature, with no explanation relating to the two distinct phases of charnockite formation as envisioned by Naha et al. [15].

Secondly, it is intriguing that none of the workers dealing with the in situ transformation of amphibolite facies gneiss to patchy charnockites at Kabbaldurga, South Karnataka, have recognized or reported the presence of mafic granulites, which are abundant in the quarries of Kabbaldurga and the neighborhood. Only Naha et al. [15] reported some boudinaged charnockite-basic granulite invaded by pegmatitic charnockite veins from M.M. Hills. It is also important to note that Naha et al. [15] described "pods and patches of basic granulites of diverse shapes, seemingly bare of any pattern within the charnockites, may represent different parts of a refolded fold torn asunder" from Shivasamudram. And Bhattacharya and Sen [18] reported abundant mafic granulite bands and boudins from the Kabbaldurga and its neighborhood. The presence of mafic granulite enclaves in the Kabbaldurga quarries and the neighborhood also demand some explanation in relation to the development of patchy charnockites. Unfortunately again workers dealing with development of patchy charnockite have not explored the possible genetic link between the mafic granulite and patchy charnockite in these quarries of South Karnataka. Bhattacharya and Sen [18] also pointed out that the metasomatising fluid (causing the gneiss to charnockite transformation) did not affect the mafic granulites here.

The foregoing lines show that two important questions still remain unresolved. First, the relation of the patchy charnockite (incipient charnockite) to the mafic granulites is not explained in the hypothesis of incipient growth by $\mathrm{CO}_{2}$-fluid ingress. Second, the pre-existing deep crustal granulites [17], or the exposed mafic granulites at Kabbaldurga, could represent the distinct phase of charnockite formation in time from the incipient charnockite [15] and hence the conception of a transition zone in South Karnataka needs to be re-examined in relation to the crustal evolution in South India.

Recently we have undertaken fieldwork in the Kabbaldurga and its neighborhood with the specific aim of re-examining field relations and sampling the closely related patchy charnockites, gneisses and mafic granulites.

In the present communiqué, we present critical field features in addition to trace element and isotopic data on some earlier samples (as reported in 18) of Kabbaldurga, and try to suggest possible answers to the aforesaid questions. In the near future we will undertake the geochemistry and isiotopic study of the samples collected during this field trip.

\section{GEOLOGICAL SETTING}

Kabbaldurga quarries and the neighborhood in South Karnataka, India, were described as a transition zone between amphibolite and granulite facies [19]. The lithological variations in the area include charnockite, mafic granulite and migmatitic Peninsular gneisses [18]. They also described the structural frame work in Kabbaldurga and its neighborhood. The pervasive foliation in the Peninsular gneisses display numerous small scale folds and common shear bands and drag folds, commonly filled with leucosomes and pink granites (non-charnockitic). Mafic granulites have variable shapes and orientation, with the pervasive foliation of the Peninsular gneiss commonly abutting against them.

Patchy charnockites in the Kabbaldurga quarries occur in two distinct field relations and associations. In relation to the gneiss, some patches definitely occupy structurally weak zones, such as shear bands, and fold noses; however, many of the charnockite patches transecting the gneissic fabric, occur as branching veins, and unrelated to any deformation fabric. Naha et al. [15] also reported "examples of blebs, patches and irregular veins of charnockite without any structural relation to that in the host gneisses and Closepet Granite are abundant". Hence the hypothesis of $\mathrm{CO}_{2}$ fluid pathways is difficult to explain such irregular, branching veins.

The other patchy charnockite patches (variety) have a unique field relation with the mafic granulite bands, boudins and enclaves. Some of these boudins are veined by orthopyroxene-bearing leucosomes. And many of the mafic granulites have coarse-grained charnockitic rims and margins.

The sample locations have been shown in Figure 1.

\section{FIELD FEATURES}

Some of the distinguishing features observed in the field that could argue against the in situ transformation of the gneiss into patchy charnockites, are described in the following.

\subsection{Patchy Charnockite in Relation to Migmatitic Peninsular Gneisses}

Kabbal quarry no. 4: $12^{\circ} 29^{\prime} 40.92^{\prime \prime N}$; 77 $18^{\circ} 3.42^{\prime \prime E}$. 
The dominant light-grey, finely laminated gneisses along with intricately folded mafic selveges, and grey gneiss component (top-right) demonstrate the migmatitic nature of Peninsular gneiss at Kabbaldurga. Some of the patchy charnockite bodies do appear to occupy fold noses, although relatively larger bodies also follow the gneissic foliation for a considerable length (Figure 2). These patches are restricted to the granitic gneiss component only.

Charnockite patches across gneissosity:

Kabbal quarry no. 1: 12²9'53.58"N; $77^{\circ} 18^{\prime} 5.46^{\prime \prime}$.

At this location a greasy charnockite patch, which incorporates relic gneissosity, occurs across the gneissosity of the Peninsular gneiss (Figure 3). With no apparent structure/weak zone, fluid pathway mechanism for in situ transformation could not be validated. Moreover, threedimensional disposition of coarse greasy charnockite transecting the gneissic foliation as branching vein has also been observed at this location, along with different gneissic components, dominant light-grey granitic gneiss and tonalitic grey-gneiss (Figure 4). Within dominantly tonalitic grey-gneiss variety also branching charnockite veins are observed and with no structural weak zone here, fluid-pathway hypothesis could not be validated (Figure 5).

$12^{\circ} 29^{\prime} 48.54^{\prime \prime} \mathrm{N} ; 77^{\circ} 18^{\prime} 5.7^{\prime \prime} \mathrm{E}$. Kabbaldurga quarry, 3.

Some charnockite patches definitely occur in structural weak zones such as shear bands and may represent channel ways for fluid ingress (Figure 6). However, coarse greasy charnockite in a sinistral shear vein, branching away along the gneissosity, could be explained differently. Rather than $\mathrm{CO}_{2}$-fluid pathway, localization of anatectic melt in structural weak zones can be a better explanation. First and foremost the Peninsular gneiss in this location displays stromatitic migmatite structures, including regular leucosome and mesosome layers, and some mafic selveges. The charnockitic vein on the other hand, could define melt migration along the shear zone and moving out along the pre-existing migmtitic foliation in the host Peninsular gneiss. Note that the migmatitic foliation is significantly dragged at the margins of the shear zone, while there is minimal, if any, effect on the branching charnockite vein.

\subsection{Patchy Charnockite in Relation to Mafic Granulite Enclaves}

Yelachipalyam quarry no. $2: 12^{\circ} 39^{\prime} 9.18^{\prime \prime} \mathrm{N}$; $77^{\circ} 14^{\prime} 15.12^{\prime \prime} \mathrm{E}$.

A greasy charnockite (below the pen) layer occur at the margin of a mafic granulite body along with two distinct components of Peninsular gneiss, pink granite without perceptible gneissic fabric and light grey granitic gneiss with gneissic fabric at acute angle to the pink granite layer. While the pink-granite layer may be related to the gneiss as late leucosome; the charnockitic layer at the margin of the mafic granulite body could be described as a leucosome derived from and remained frozen on the mafic granulite. Anatectic melt-pockets are also seen within the mafic granulite (bottom of the photograph) (Figure 7).

Kabbaldurga quarry no. $6.12^{\circ} 29^{\prime} 35.16^{\prime \prime N} ; 77^{\circ} 18^{\prime} 5.1^{\prime \prime E}$.

A small mafic granulite enclave is encased by coarse, greasy charnockite (Figure 8). The coarse charnockite rimming the mafic granulite body could be considered as initial stage of anatexis when the anatectic melt did not escape and remained frozen on the mafic source rock.

Yelachipalyam quarry no. 1 : $12^{\circ} 39^{\prime} 9.18^{\prime \prime} \mathrm{N}$, $77^{\circ} 14^{\prime} 15.12^{\prime \prime} \mathrm{E}$

At this location, orthopyroxene-bearing leucocratic vein occurs within mafic granulite enclave (Figure 9). This vein is restricted to the mafic granulite body and hence appears to be internally derived.

\subsection{Mafic Granulite Protoliths Older than the Pervasive Gneissosity in the Host Peninsular Gneiss}

Kabbaldurga quarry no. $1: 12^{\circ} 29^{\prime} 53.58^{\prime \prime N}$; $77^{\circ} 18^{\prime} 5.46^{\prime \prime E}$. In this quarry, a mafic granulite enclave within the Peninsular gneiss with gneissosity abutting against irregular margin of the enclave clearly indicates the xenolithic nature of mafic granulite (Figure 10). A folded and dismembered mafic granulite band, with the discordant nature of folds and gneissosity dissecting the mafic granulite band, indicates the prior existence of the mafic granulite-protolith with respect to the gneissosity (Figure 11).

\section{PETROGRAPHIC FEATURES}

The prograde nature of the hornblendes in mafic granulite is indicated by orthopyroxene and plagioclase on the embayed hornblende margin (Figure 12(a)). This together with $\mathrm{Mg}$-enrichment at hornblende margin, as reported earlier (Bhattacharya and Sen, 2000) [18] is consistent with hornblende-dehydration melting and the restitic nature of the mafic granulites at Kabbaldurga. On the other hand many of the charnockite patches, both in relation to gneisses and mafic granulites record rehydration of pyroxenes to hornblende and biotite, as expected during cooling and crystallization of melts (Figures 12(b) and (c)).

\section{GEOCHEMISTRY}

All together twelve samples have been analyzed for trace elements by ICP-MS, including four patchy charnockites, three mafic granulites, three peninsular gneisses from Kabbaldurga quarries, and two massive type charnockites from the neighborhood. Major element composition by XRF was reported earlier (Bhattacharya and 


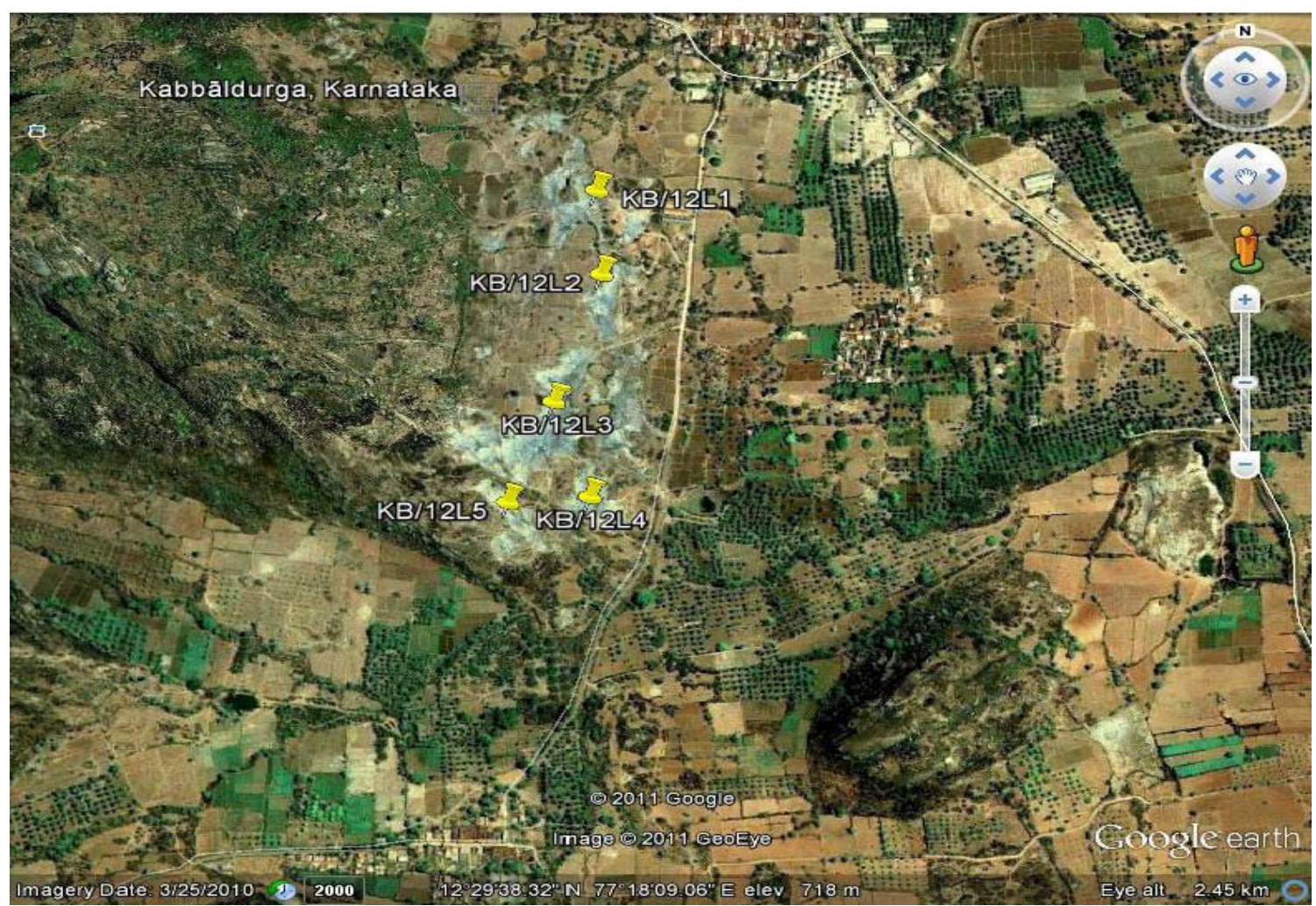

(a)

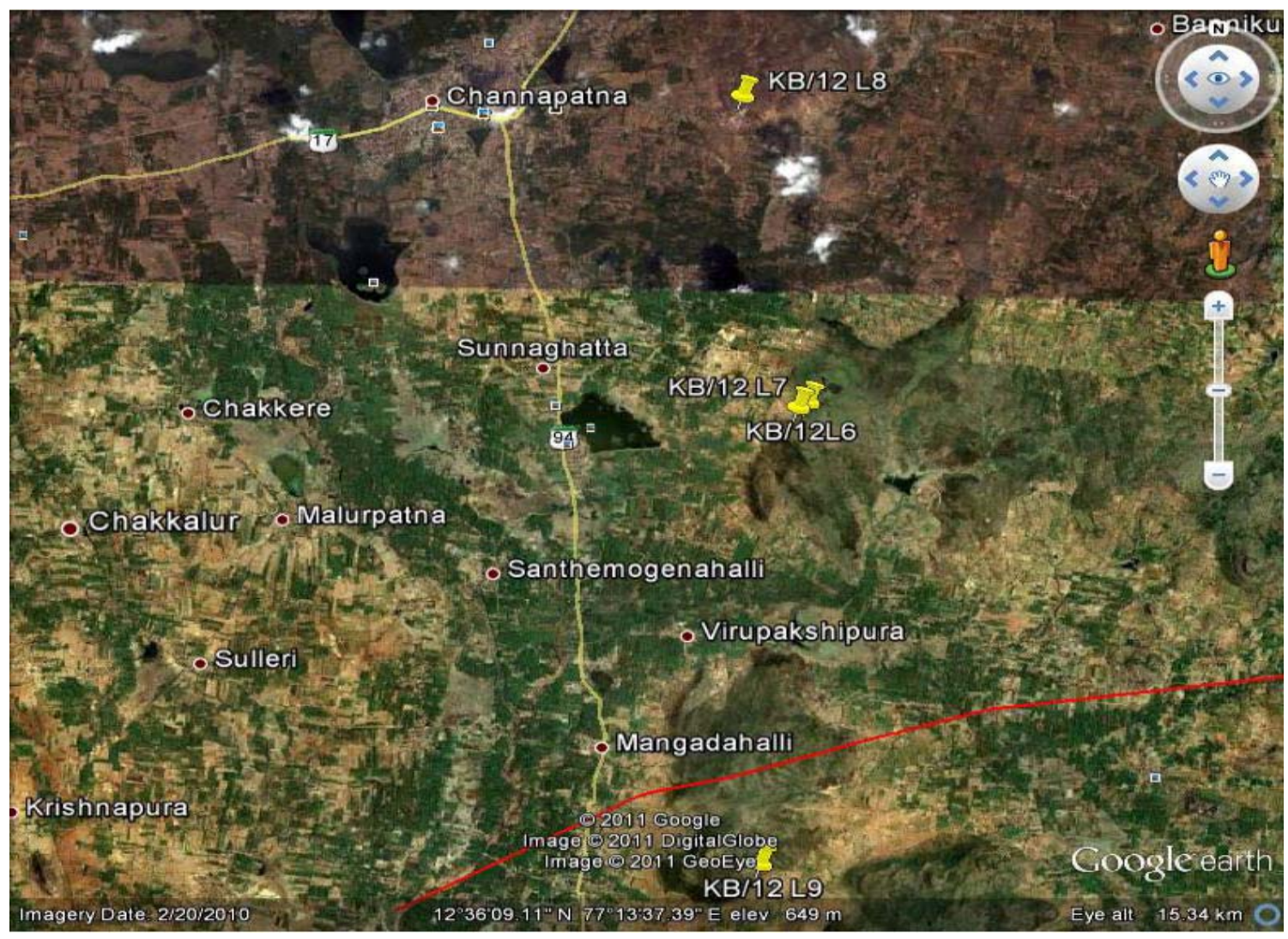

(b)

Figure 1. (a) \& (b): Sample locations are shown on Google images. 


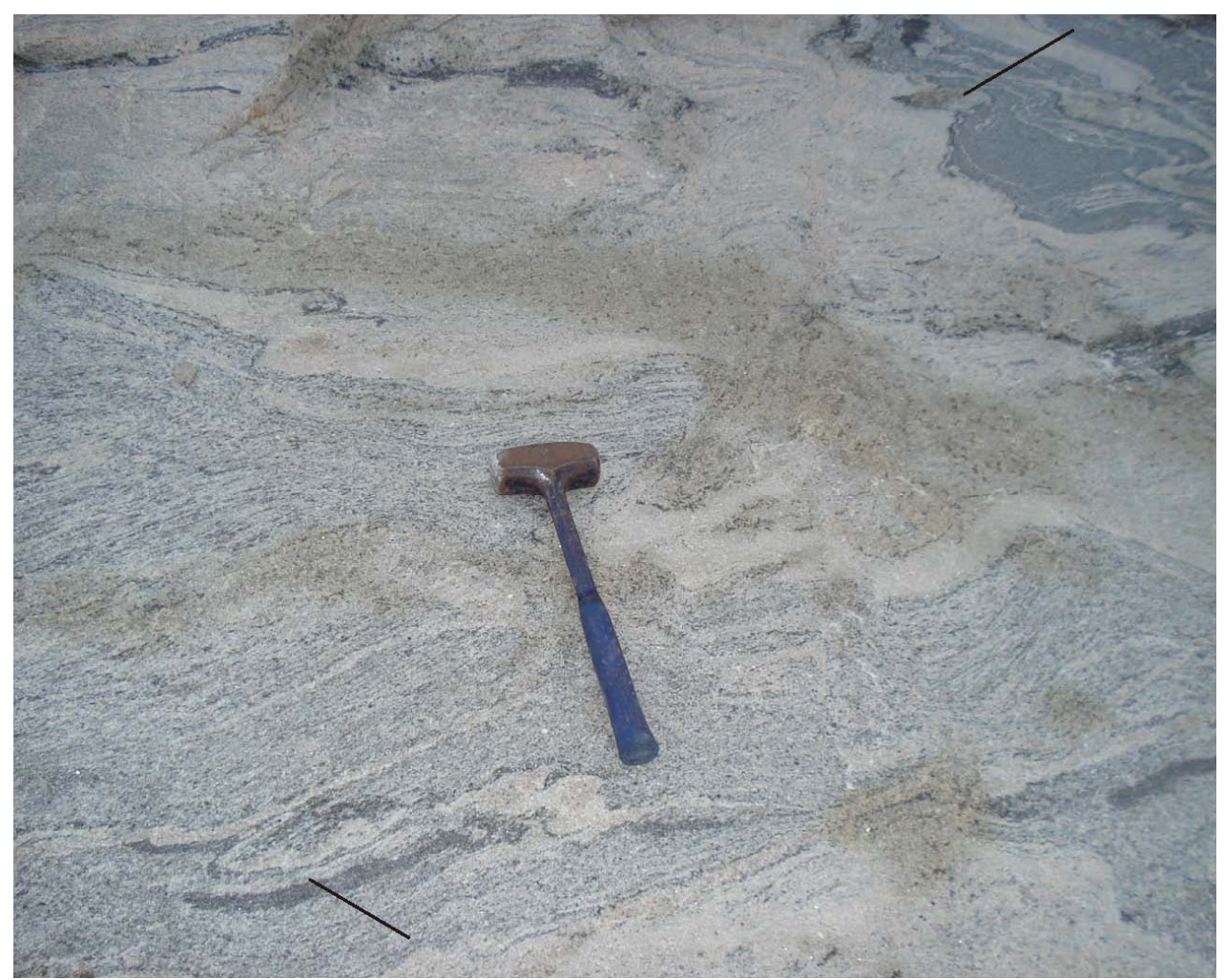

Figure 2. Migmatitic nature of Peninsular gneisses: the dominant light grey, finely laminated gneiss along with mafic selveges; dark grey- gneiss with some leucocratic layers, depict intricate folds, upper right corner. Charnockite patches here are restricted to granitic gneiss; some small patches occur at fold noses, some others follow the gneissic foliation.

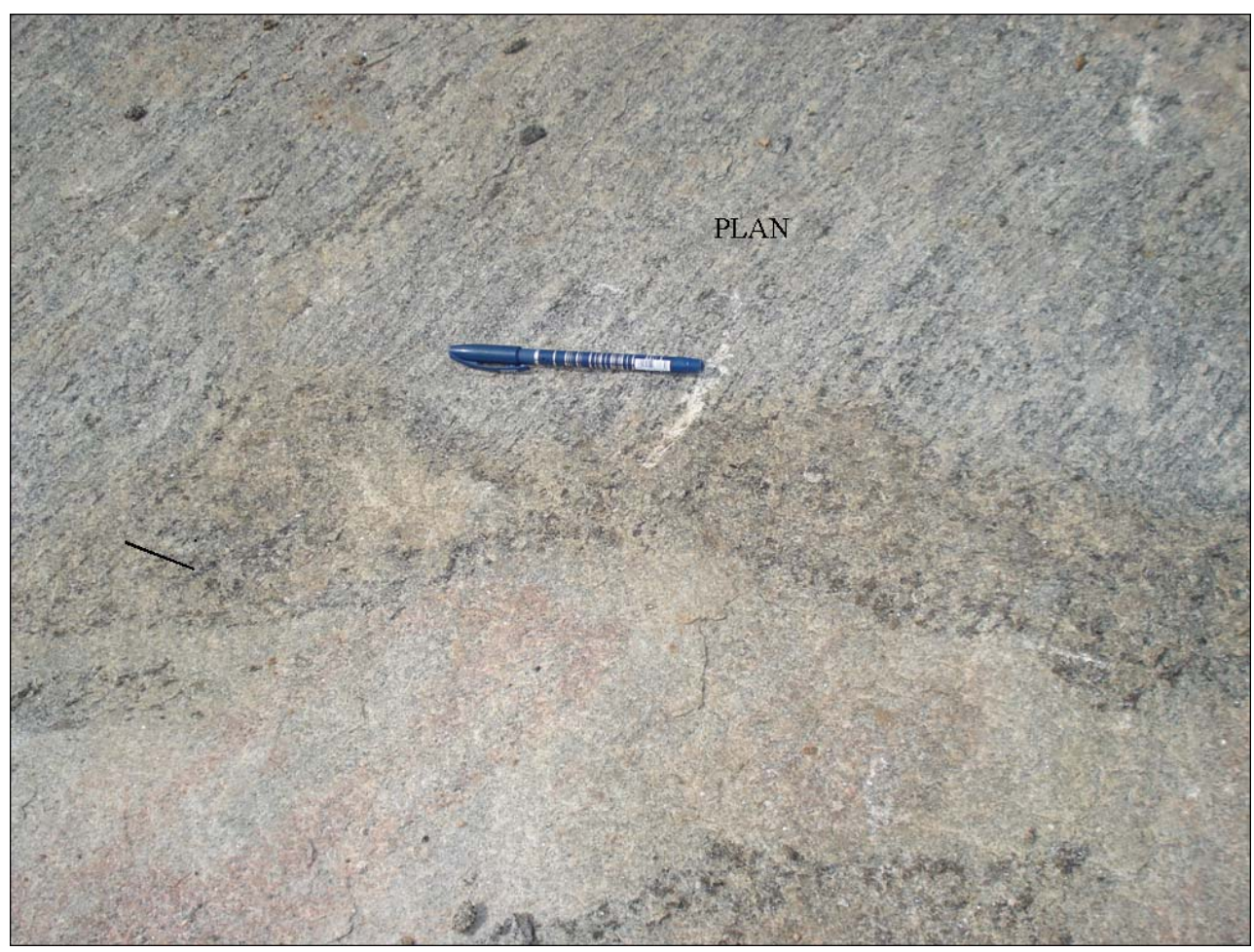

Figure 3. Planar view of greasy charnockite patch across gneissosity of the peninsular gneisses. Charnockite patch incorporates relict gneissic foliation. 


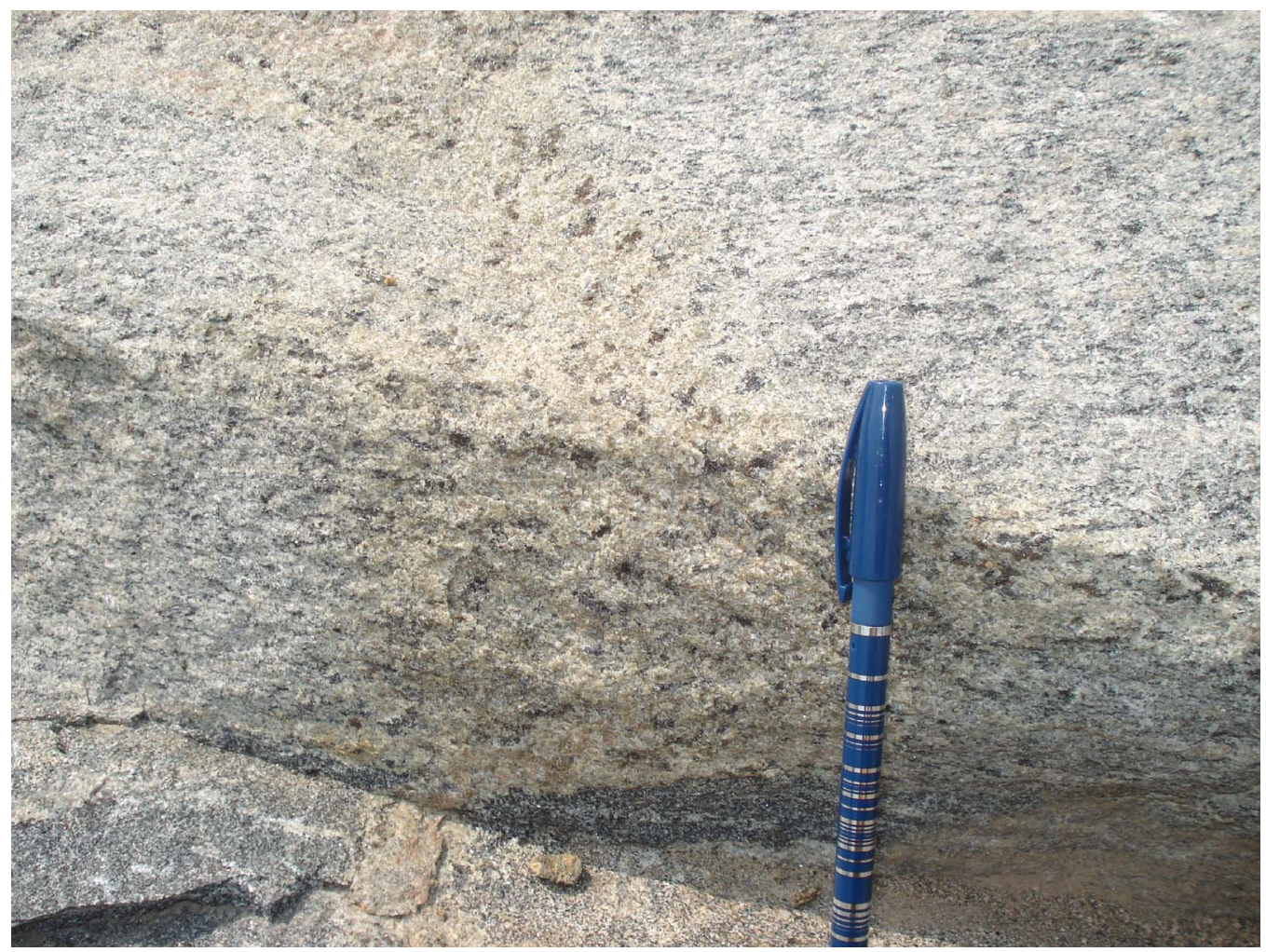

Figure 4. Three-dimensional disposition of coarse greasy charnockite, transecting the gneissic foliation, as a branching vein, along with different gneissic components, dominant light-grey granitic gneiss and tonalitic grey-gneiss, are observed.

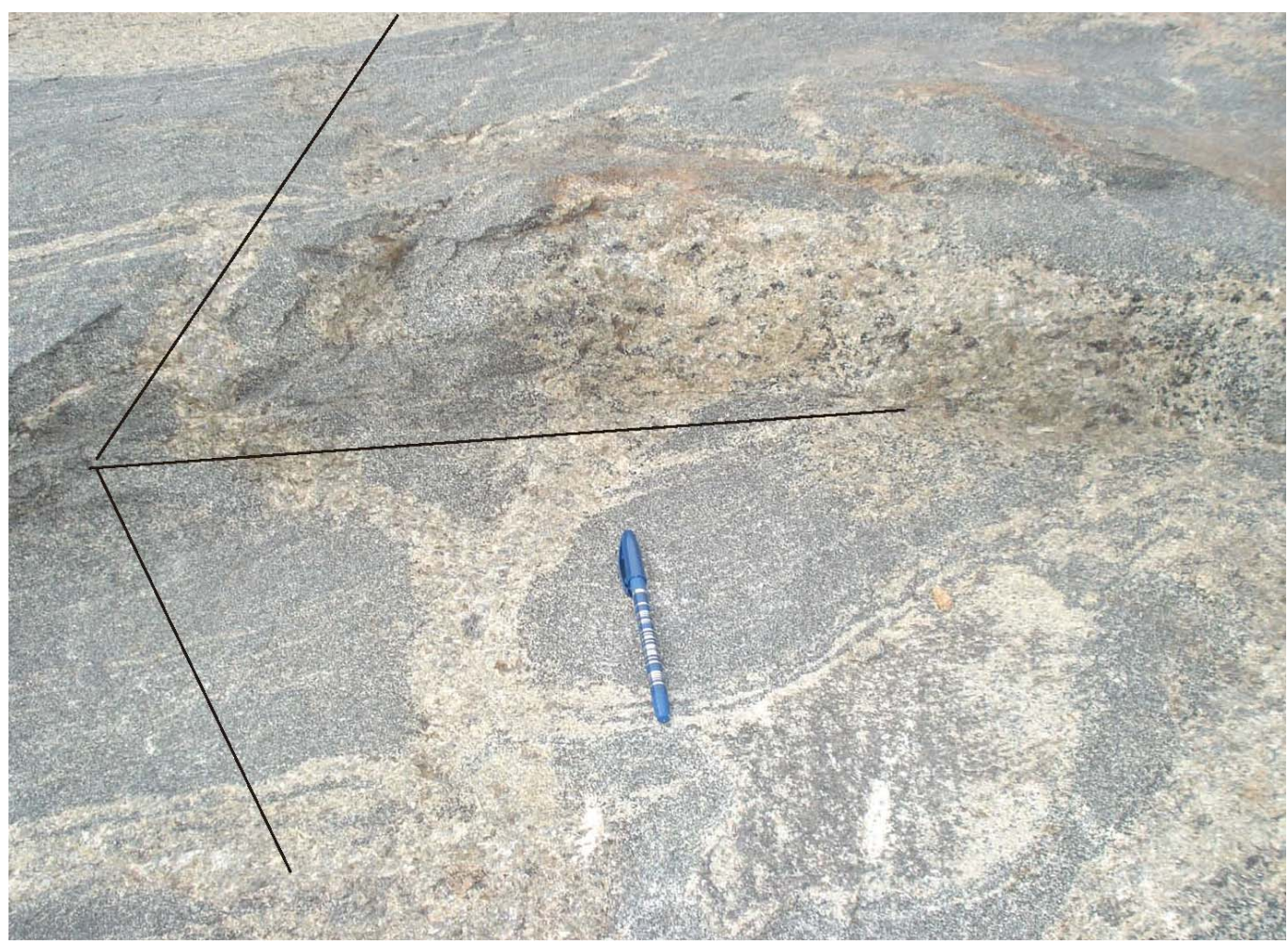

Figure 5. Three dimensional view of a coarse, greasy charnockite as branching vein; host gneiss is here the dark grey-gneiss variety. 


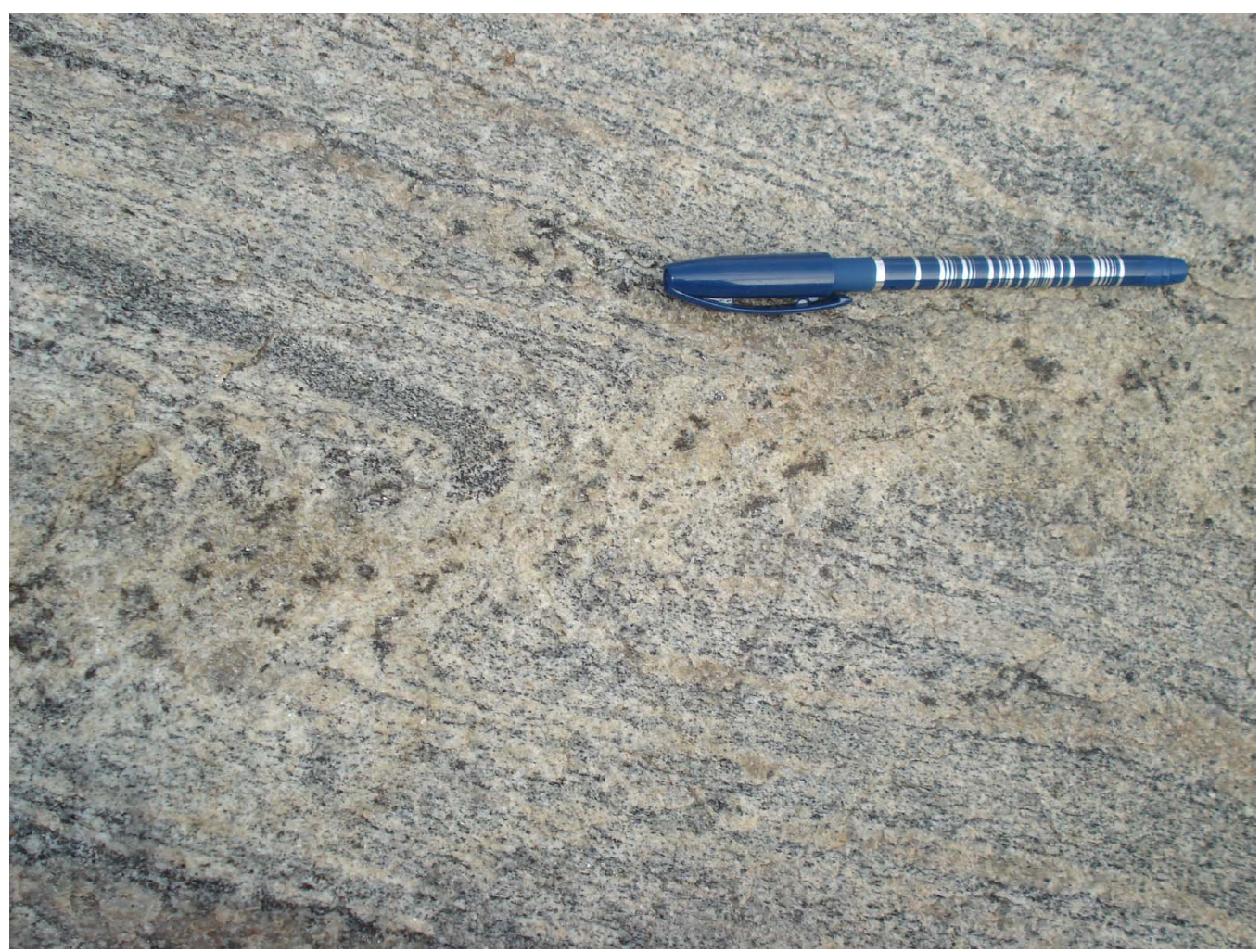

Figure 6. A coarse-grained and greasy charnockite occurs in a sinistral shear vein, branching away along the gneissosity.

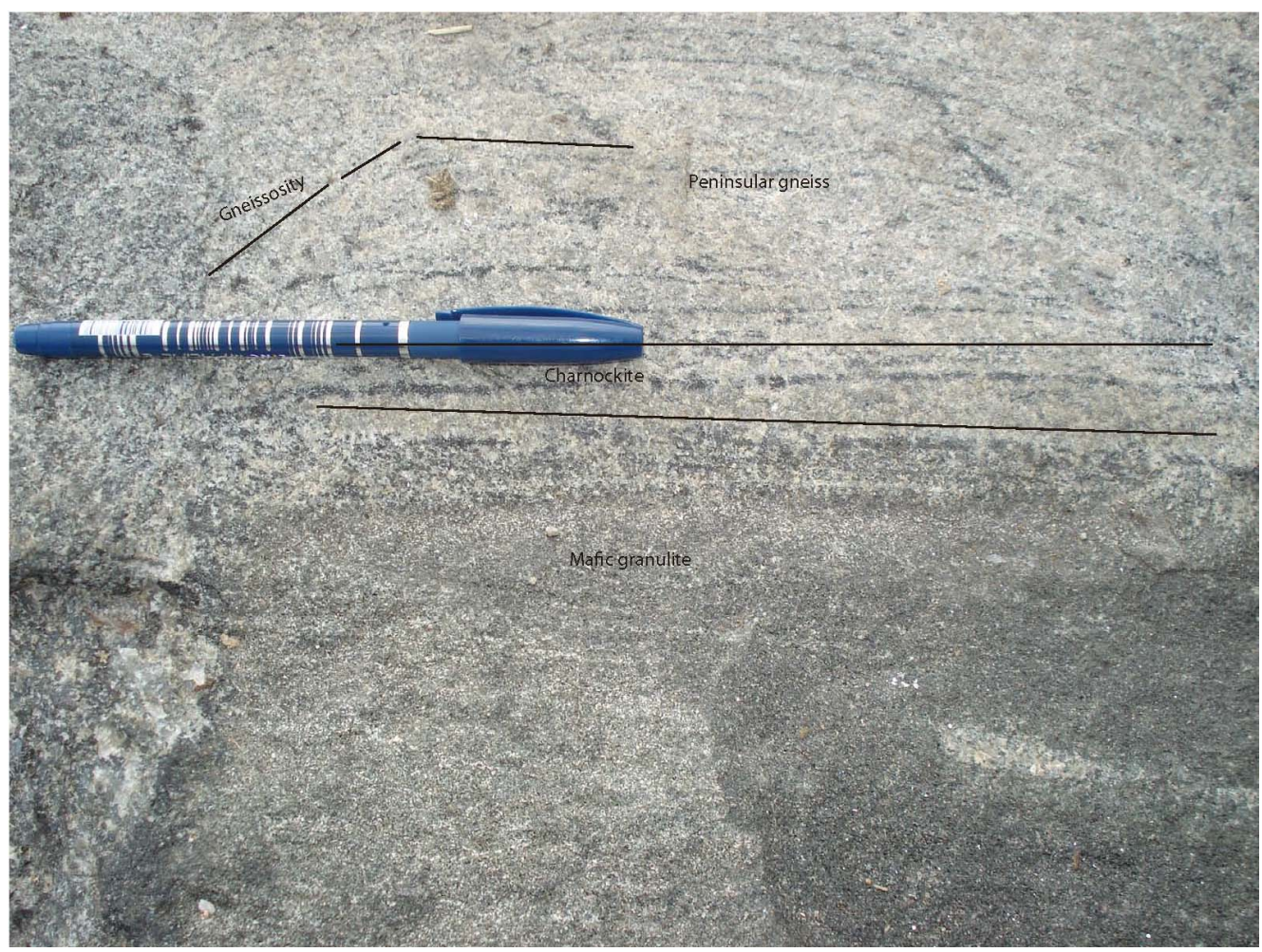

Figure 7. A greasy charnockite (below the pen) layer occurs at the margin of a mafic granulite body along with two distinct components of Peninsular gneiss. Light grey granitic gneiss with the gneissic fabric at acute angle to the pink granite layer. 


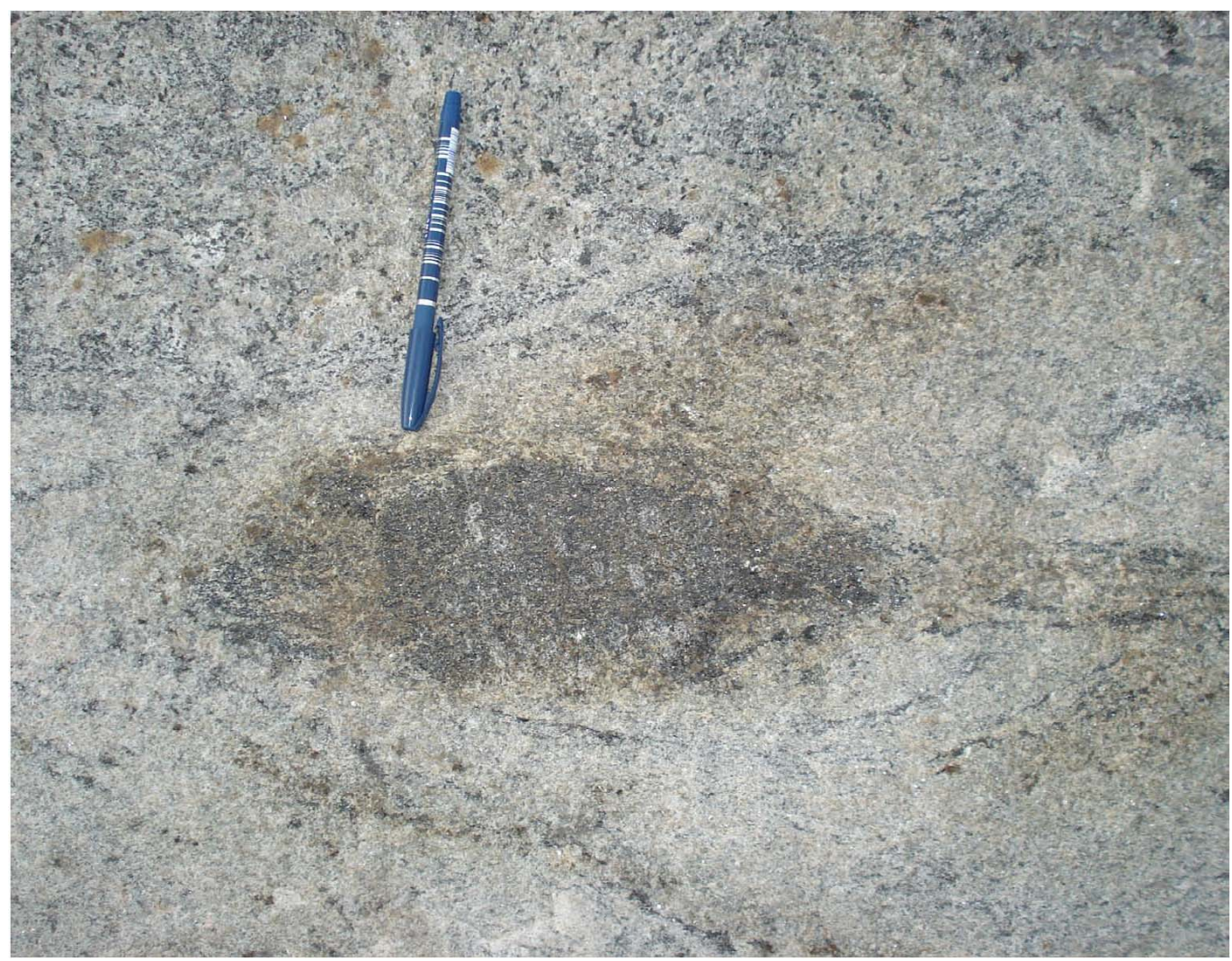

Figure 8. A small mafic granulite enclave rimmed by coarse, greasy charnockite.

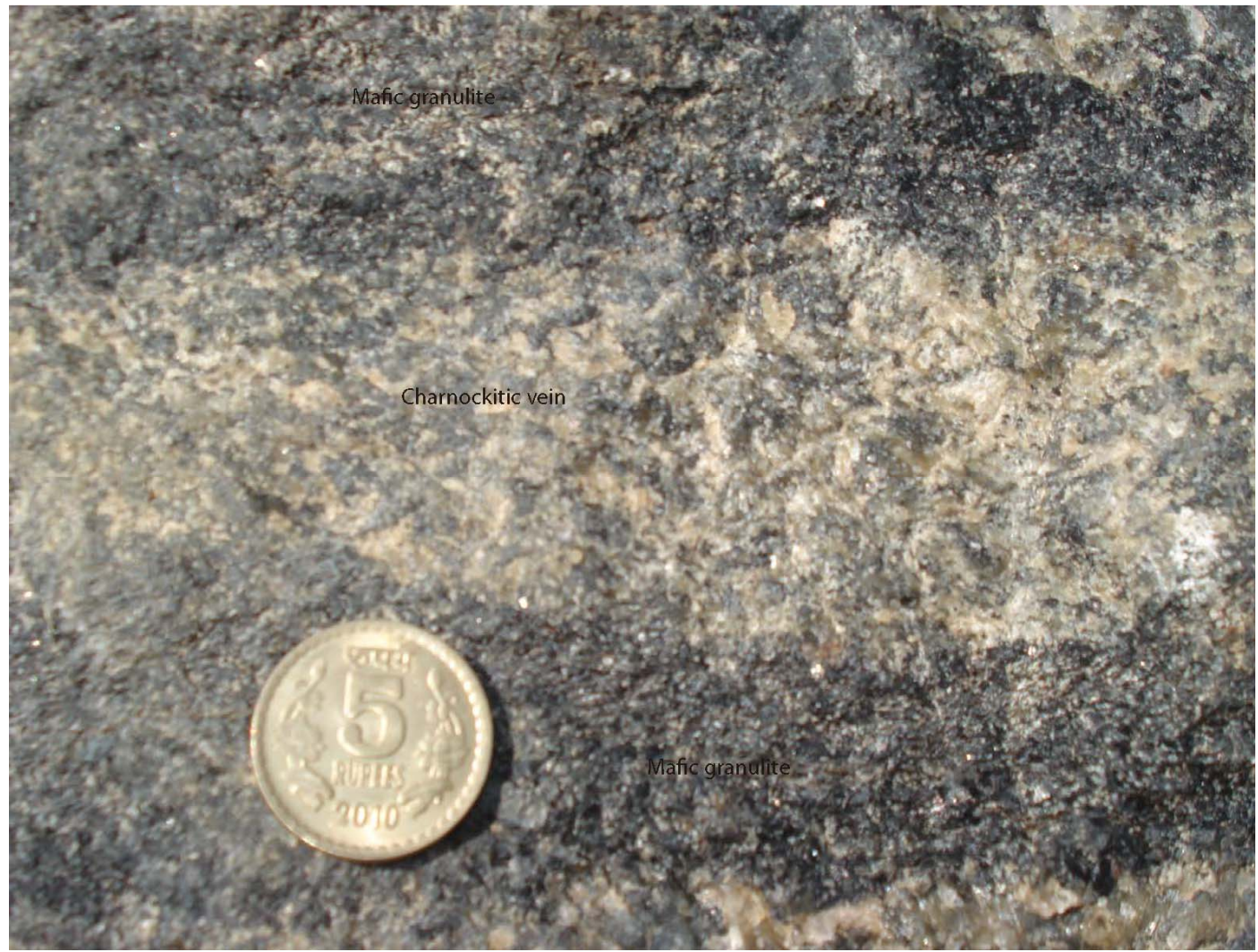

Figure 9. Orthopyroxene-bearing leucocratic vein within a mafic granulite enclave. 


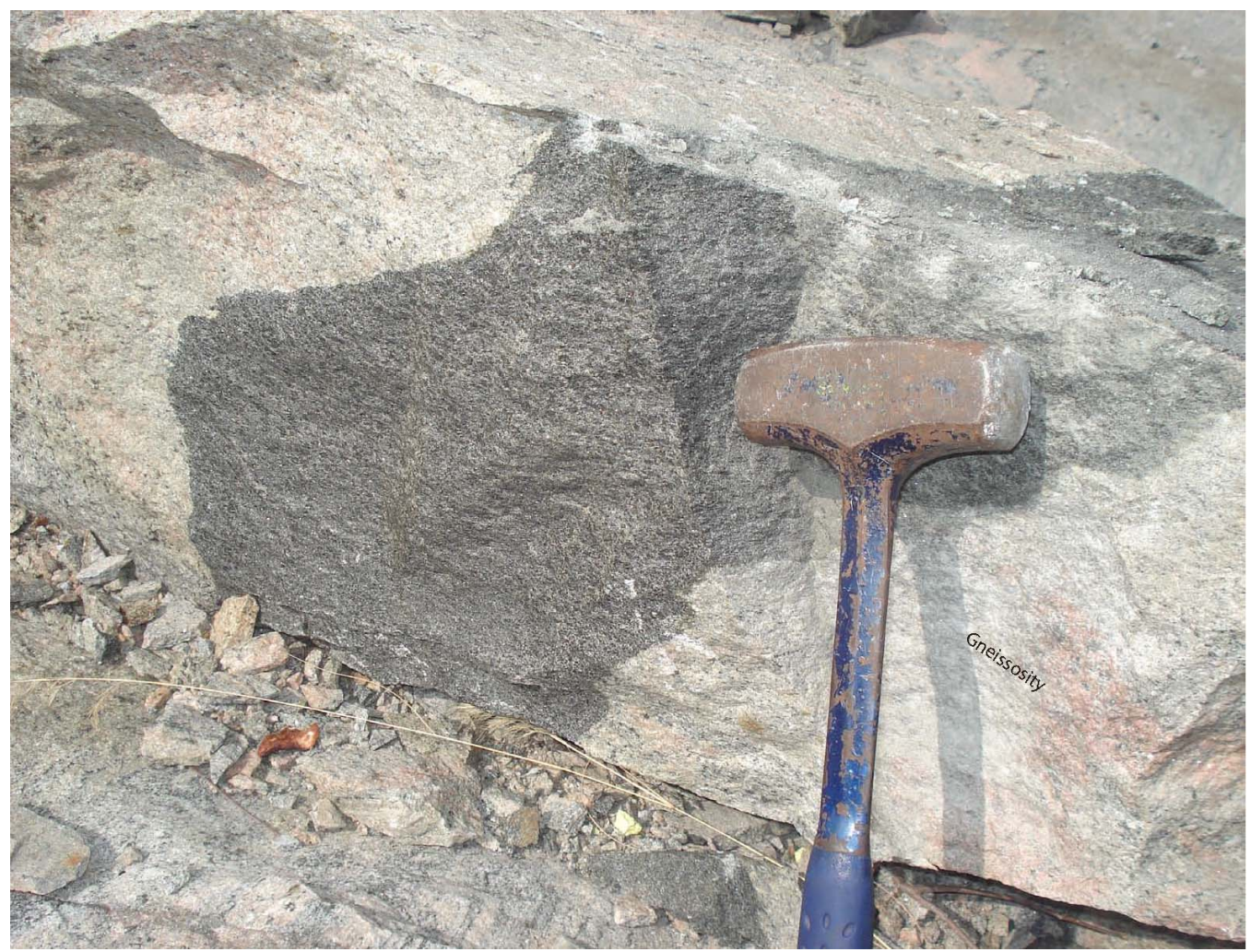

Figure 10. A mafic granulite enclave within Peninsular gneiss; gneissosity penetrating the mafic enclave.

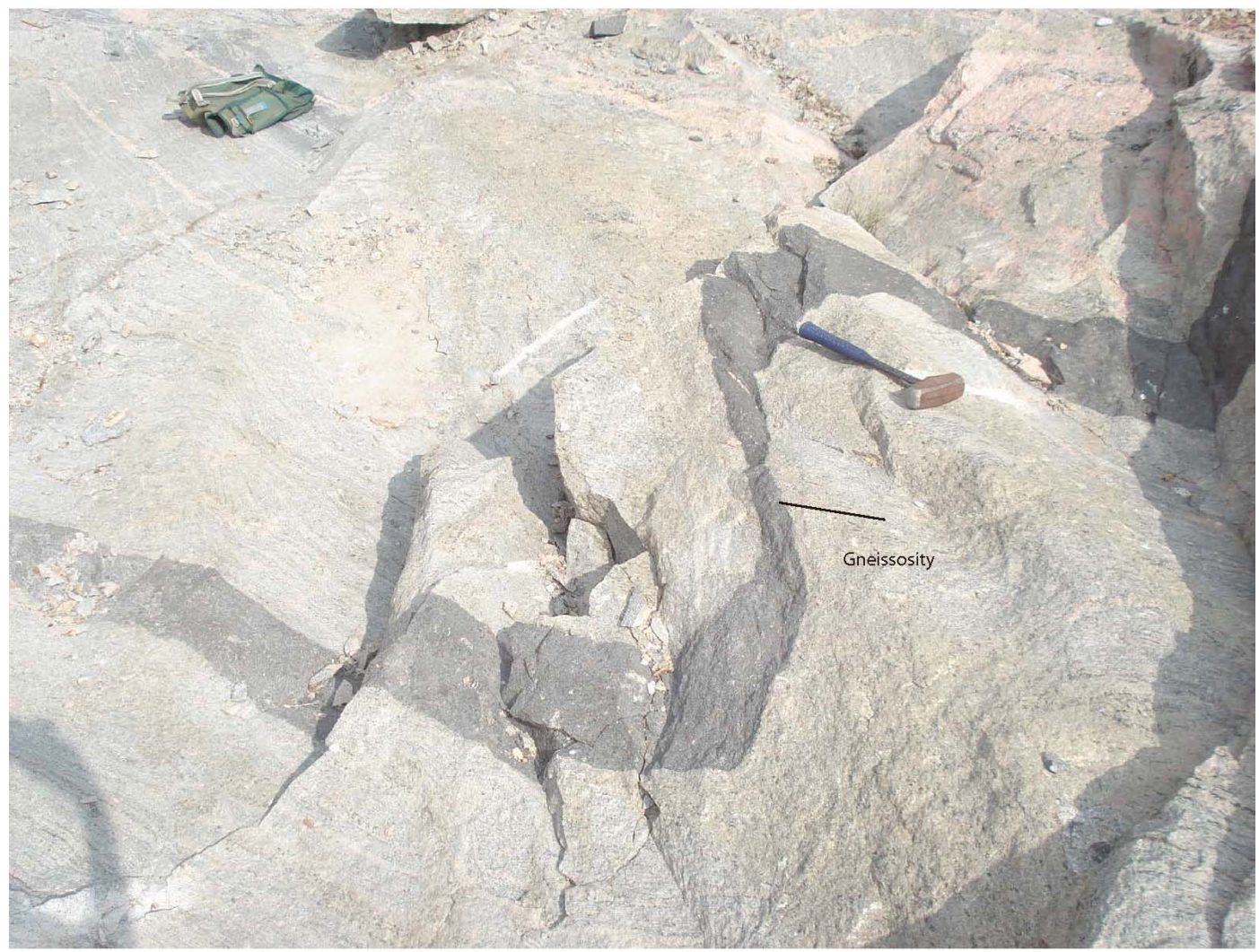

Figure 11. Folded and dismembered band of mafic granulite. Although, gneissosity is also folded, discordant nature of the folds and gneissosity at places penetrates the mafic granulite band. 


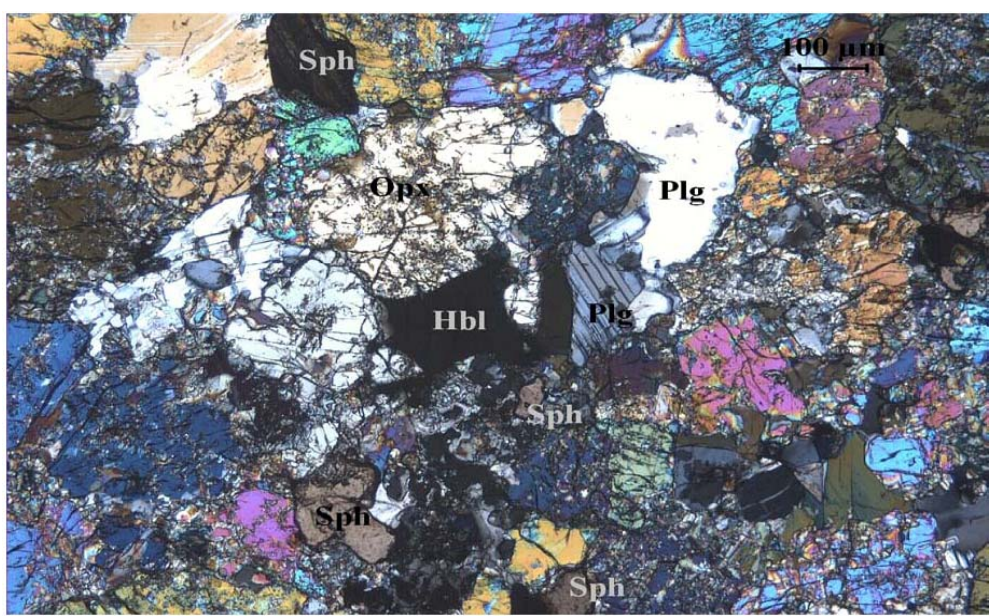

(a)

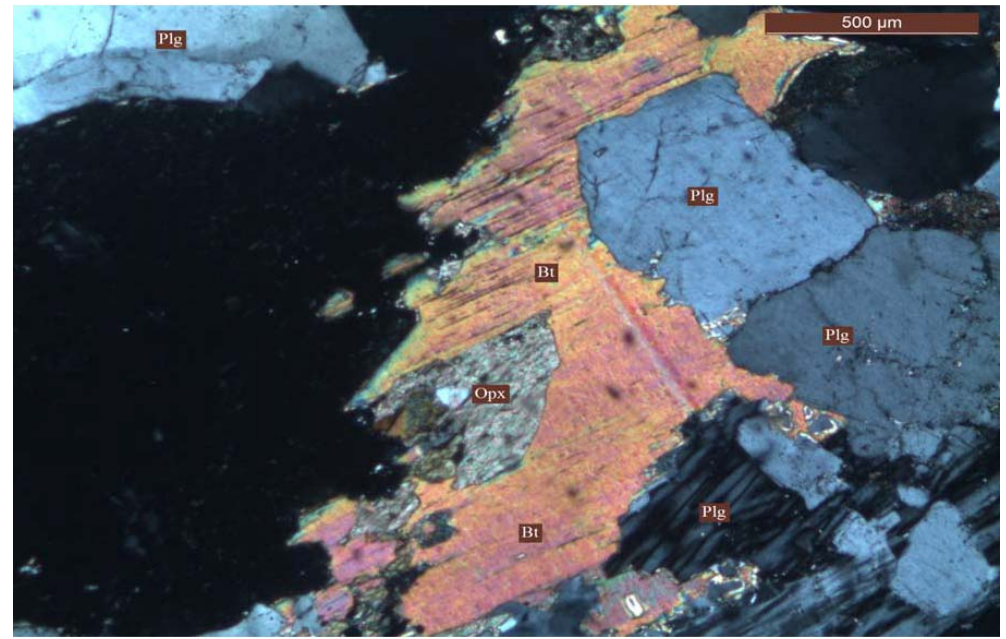

(b)

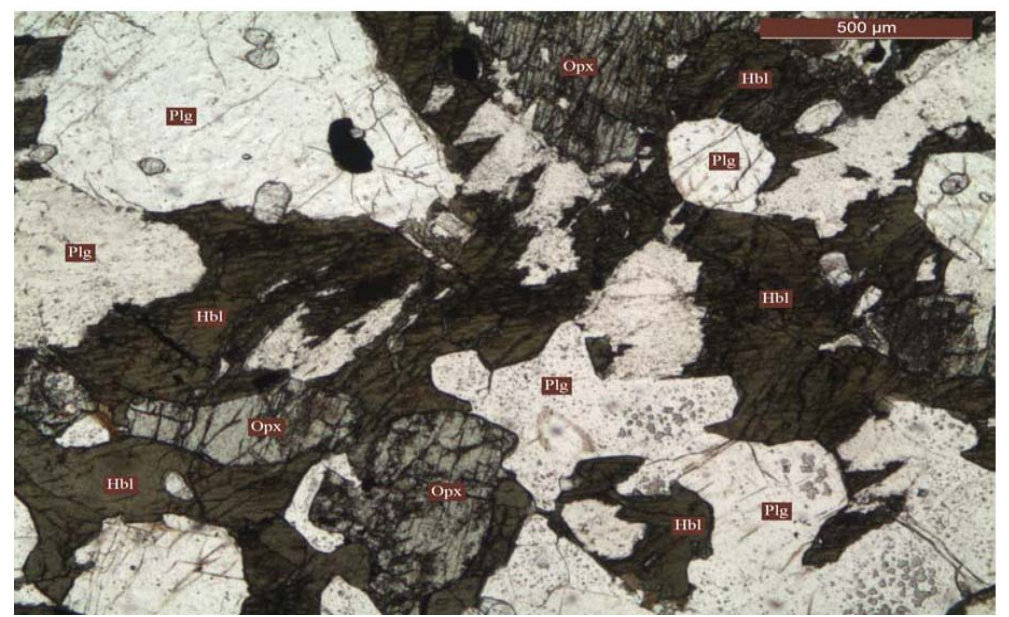

(c)

Figure 12. Photomicrographs: (a) Orthopyroxene and plagioclase at the embayed hornblende margin, attesting to prograde nature of hornblende in mafic granulite; (b) Relict orthopyroxene within biotite in a charnockite layer (rind) at the margin of a mafic granulite enclave, indicating rehydration possibly during cooling and crystallization of the melt; (c) Secondary hornblende at orthopyroxene margin in a charnockite patch, also attest to rehydration. 
Sen, 2000) [18]. Potassium and Titanium data have been reproduced from the earlier publication. Trace elements including rare earth elements and isotopic analyses were carried out at the Institute Instrumentation Centre, IIT, Roorkee by means of an Inductively Coupled Plasma Mass Spectrometer, and a Thermal Ionization Mass Spectrometer respectively. Details of the analytical procedures were described in Bhattacharya et al. (2011) [20]. For trace elements in general the RSD for all the elements is much less than $4 \%$. Individually they are less than $2.5 \%$ for alkali and alkaline earth metals ( $\mathrm{Rb}: 2.23$, Sr: $1.38 \%$ and Ba: $1.55 \%$ ), less than $2 \%$ for the transition elements except for Sc and $\mathrm{Hf}(\mathrm{Zr}: 0.9, \mathrm{Nb}: 1.07, \mathrm{Ni}: 1.8$, Cr: 1.4, V: 1.43, Co: 1.28, Sc: 10, Hf: 3.18 and $\mathrm{Cu}: 1.6)$, within 3\% for LREE (La: 1.2, Ce: 1.0, Nd: 1.6, Eu: 2.5, Sm: 3.0 and Pr: 2) and within $4 \%$ for HREE (Dy: 2.2, Tb: 2.2, Gd: 2.4, Ho: 2.8, Er: 3.2, Yb: 3.4, Tm: 3.4 and Lu: 3.9). For the isotopic analysis the total procedure blank in the laboratory was less than $8 \mathrm{ng}$ of $\mathrm{Sr}$ and $\sim 1 \mathrm{ng}$ of $\mathrm{Nd}$ during the period of analysis.

\subsection{Results}

\subsubsection{Trace Element}

The trace element composition of the twelve analyzed samples is given in Table 1. The patchy charnockites of Kabbaldurga quarries are poor in transitional trace elements: $\mathrm{Cr}(4.4$ - 32.3), average $13.7 \mathrm{ppm}$; and $\mathrm{Ni}(8.7$ 16.8), average $9.9 \mathrm{ppm}$; these values are similar to those in the Peninsular gneisses: $\mathrm{Cr}$ (average $5.6 \mathrm{ppm}$ ), and $\mathrm{Ni}$ (average $6.2 \mathrm{ppm}$ ). But mafic granulites are considerably enriched in them: $\mathrm{Cr}$ (average $88 \mathrm{ppm}$ ) and $\mathrm{Ni}$ (average $64 \mathrm{ppm}$ ) respectively. Base metal $\mathrm{Cu}$ is variable in the charnockites, between 10.7 and 56.6 (average 34 ppm), similar to those in the mafic granulites (average 34.2 ppm), but Peninsular gneisses are poor (average 9.3 ppm); Zn: 34.8 - 71.7 (average 59.6 ppm), less than those in the mafic granulites (average $102.9 \mathrm{ppm}$ ), and comparable to those in the gneisses (average $53 \mathrm{ppm}$ ). $\mathrm{Ti}$ is comparable in the charnockites and mafic granulites, average 4683 and $4578 \mathrm{ppm}$ respectively, but much higher than those in the gneisses, average $2838 \mathrm{ppm}$. Incompatible elements, $\mathrm{K} \& \mathrm{Ba}$ are enriched in the charnockites, averaging $11,347 \& 348 \mathrm{ppm}$, compared to those in the mafic granulites, averaging $8187 \& 149.2$ $\mathrm{ppm}$ respectively. However, $\mathrm{Rb}$ is comparable between the charnockites and mafic granulites, averaging 46 and $48.7 \mathrm{ppm}$ respectively. On the other hand, gneisses are more enriched in $\mathrm{K} \& \mathrm{Rb}$, averaging $14,798 \& 88.8 \mathrm{ppm}$ respectively, while $\mathrm{Ba}$ contents are similar to those in the charnockites, averaging $469.5 \mathrm{ppm}$. Sr is relatively depleted in the charnockites, averaging $277.5 \mathrm{ppm}$, compared to those in the mafic granulites, averaging 596.8 ppm. Trace elements $\mathrm{Y}, \mathrm{Zr} \& \mathrm{Nb}$ are highly variable in the charnockites. Y (11.7 - 130.7), averaging $59 \mathrm{ppm}$, similar to those in the mafic granulites \& gneisses, averaging 38.1 and 53.5 ppm respectively. $\mathrm{Zr}(89.7$ - 356.4), averaging $232 \mathrm{ppm}$ in the charnockites, similar to those in the gneisses, averaging $270 \mathrm{ppm}$, but expectedly much higher than those in the mafic granulites, averaging 49.9 ppm. $\mathrm{Nb}(1.8-48.3)$, averaging $21 \mathrm{ppm}$ in the charnockites, similar to those in the mafic granulites, averaging $26.2 \mathrm{ppm}$, but higher than those in the gneisses, averaging $7.3 \mathrm{ppm}$. Patchy charnockites of Kabbaldurga quarries are significantly enriched in $\mathrm{K} \& \mathrm{Ba}$, but depleted in $\mathrm{Sr}$ relative to the mafic granulites, on the other hand, transitional and base metals $\mathrm{Cr}$, Ni \& $\mathrm{Zn}$ are significantly depleted in the charnockites relative to the mafic granulites (Figure 13). These complementary trace element features, between the charnockites and mafic granulites, is consistent with a genetic link between them via partial melting: as melt and restite respectively. $\mathrm{Sr}$ depletion in melt of granitic composition (whole rock composition reported in Bhattacharya and Sen, 2000) [18] indicates both hornblende and plagioclase as restitic phases. Two massive-type charnockites are significantly more enriched in incompatible elements $\mathrm{K}, \mathrm{Rb} \& \mathrm{Ba}: \mathrm{K}$ $(13,277 \& 15,351 \mathrm{ppm}), \mathrm{Rb}(97.8 \& 99.8 \mathrm{ppm})$ and $\mathrm{Ba}$ $(15,26.4 \& 1297.2 \mathrm{ppm})$, as against those in the patchy charnockites: average $11,347,46 \& 348$ ppm respectively. Unlike the patchy charnockites, the massive charnockites are not depleted in $\mathrm{Sr}$ (201.3 \& $885 \mathrm{ppm})$. Transitional and base metals like $\mathrm{Cr}, \mathrm{Ni}, \mathrm{Cu} \& \mathrm{Zn}$ are depleted in the massive charnockites: $\mathrm{Cr}(22.4 \& 25 \mathrm{ppm}), \mathrm{Ni}(9.3 \&$ $18.3 \mathrm{ppm}), \mathrm{Cu}(14.3 \& 42 \mathrm{ppm})$ and $\mathrm{Zn}(61.2 \& 66.2$ ppm); similar to the patchy charnockites. But unlike the patchy charnockites the massive charnockites are depleted in $\mathrm{Y}(14.8 \& 44.3 \mathrm{ppm})$ and $\mathrm{Nb}(8.4 \& 7.1 \mathrm{ppm})$, as against the average $59 \& 21 \mathrm{ppm}$ respectively in the patchy charnockites. While Sr depletion and lack of Y depletion in the patchy charnockites suggests both hornblende and plagioclase as residual phases, Y depletion and lack of Sr depletion in the massive charnockites indicate hornblende and garnet, but not plagioclase in the residue. $\mathrm{Y} \& \mathrm{Nb}$ depletion in the massive charnockites also indicate more complete interaction and separation of the melt from the residue. And in contrast $\mathrm{Y}, \mathrm{Zr}$ and $\mathrm{Nb}$ enrichment in the patchy charnockites, in addition to high $\mathrm{Cu}$ content, are indicative of disequilibrium resulting from rapid segregation and hence lack of interaction between melt and residue.

Trace elements in the peninsular gneisses are not significantly, if at all, different from those in the patchy charnockites. Particularly important are $\mathrm{Cr}$, Ni \& $\mathrm{Zn}$ contents (5.6 vs. $13.7,6.2$ vs. 9.9 and 53 vs. 59.6 ppm respectively) on the one hand, and $\mathrm{Ba} \& \mathrm{Sr}$ contents (469.5 vs. 348 and 201 vs. 277 ppm respectively) on the other. Also $\mathrm{Y}$ and $\mathrm{Zr}$ contents are comparable (53.5 vs. 
Table 1. Trace element composition of granulites and gneisses at Kabbaldurga and its neighborhood, South Karnataka, India.

\begin{tabular}{|c|c|c|c|c|c|c|c|c|c|c|c|c|}
\hline & \multicolumn{3}{|c|}{ Mafic granulites } & \multicolumn{4}{|c|}{ Patchy charnockites } & \multicolumn{2}{|c|}{ Massive charnockites } & \multicolumn{3}{|c|}{ P. gneiss } \\
\hline Sample & $\mathrm{K}-7$ & $\mathrm{~K}-15$ & $\mathrm{~K}-19$ & $\mathrm{~K}-7 \mathrm{~A}$ & $\mathrm{~K}-8 \mathrm{~A}$ & $\mathrm{~K}-9$ & $\mathrm{~K}-10$ & KB-3 & S-33 & $\mathrm{K}-4 \mathrm{~A}$ & $\mathrm{~K}-4 \mathrm{C}$ & $\mathrm{K}-6$ \\
\hline \multicolumn{13}{|c|}{ Trace elements in ppm } \\
\hline $\mathrm{Cr}$ & 136.0 & 153.3 & 94.1 & 32.3 & 12.3 & 5.8 & 4.4 & 25.0 & 22.4 & 4.6 & 5.9 & 6.4 \\
\hline $\mathrm{Ni}$ & 59.9 & 63.0 & 68.9 & 13.9 & 16.8 & 8.7 & 9.6 & 18.3 & 9.3 & 2.4 & 6.6 & 9.5 \\
\hline Co & 48.1 & 49.3 & 29.3 & 61.8 & 40.7 & 71.8 & 80.6 & 59.0 & 72.9 & 78.8 & 70.1 & 35.7 \\
\hline Sc & 20.1 & 21.4 & 3.5 & 26.6 & 18.3 & 8.4 & 3.6 & 9.3 & 14.8 & 5.6 & 8.5 & 10.7 \\
\hline $\mathbf{V}$ & 162.4 & 200.9 & 95.6 & 80.0 & 65.7 & 109.1 & 17.8 & 90.4 & 22.8 & 12.4 & 31.8 & 50.3 \\
\hline $\mathrm{Cu}$ & 3.2 & 2.5 & 97.0 & 37.0 & 56.6 & 31.8 & 10.7 & 42.1 & 14.3 & 2.1 & 11.3 & 14.5 \\
\hline Zn & 123.9 & 88.3 & 94.9 & 71.7 & 69.1 & 62.7 & 34.8 & 66.2 & 61.2 & 33.9 & 57.8 & 67.4 \\
\hline $\mathbf{K}$ & 4688.0 & 5020.0 & 14853.0 & 4439.0 & 11119.0 & 8339.0 & 16803.0 & 15351.0 & 13277.0 & 19542.0 & 13526.0 & 11327.0 \\
\hline $\mathbf{R b}$ & 31.1 & 74.4 & 40.7 & 18.2 & 35.2 & 44.0 & 86.0 & 99.8 & 97.8 & 114.1 & 95.8 & 56.6 \\
\hline Ba & 161.7 & 179.4 & 106.5 & 140.0 & 301.8 & 312.5 & 637.8 & 1297.2 & 1526.4 & 556.3 & 432.4 & 419.8 \\
\hline Sr & 656.7 & 1049.7 & 83.9 & 509.6 & 215.8 & 234.5 & 149.9 & 885.0 & 201.3 & 95.8 & 107.1 & 401.4 \\
\hline Ta & 0.5 & 0.5 & 0.4 & 0.5 & 1.4 & 0.7 & 0.0 & 0.4 & 0.2 & 0.7 & 0.1 & 0.1 \\
\hline Nb & 31.9 & 32.0 & 14.7 & 12.7 & 48.3 & 21.5 & 1.8 & 8.5 & 7.1 & 7.3 & 7.1 & 7.5 \\
\hline $\mathrm{Zr}$ & 50.9 & 50.7 & 48.2 & 356.4 & 89.7 & 271.9 & 209.5 & 139.7 & 392.4 & 214.7 & 270.1 & 326.1 \\
\hline $\mathbf{T i}$ & 4065.0 & 3461.0 & 6207.0 & 1758.0 & 9503.0 & 5383.0 & 2087.0 & 4120.0 & 3680.0 & 1538.0 & 3296.0 & 3680.0 \\
\hline $\mathbf{P}$ & 742.0 & 830.0 & 1812.0 & 830.0 & 895.0 & 851.0 & 371.0 & 1441.0 & 437.0 & 196.0 & 546.0 & 720.0 \\
\hline $\mathbf{Y}$ & 94.9 & 18.2 & 1.2 & 130.7 & 67.3 & 26.5 & 11.7 & 14.8 & 44.3 & 22.6 & 51.4 & 86.6 \\
\hline Th & 5.3 & 1.8 & 0.1 & 20.5 & 7.0 & 6.1 & 18.5 & 19.1 & 15.6 & 18.4 & 17.0 & 11.1 \\
\hline $\mathbf{U}$ & 2.0 & 2.7 & 0.8 & 2.2 & 1.5 & 1.3 & 0.5 & 0.9 & 1.1 & 0.8 & 2.7 & 0.9 \\
\hline La & 96.5 & 74.7 & 7.0 & 91.1 & 51.3 & 44.3 & 73.9 & 61.5 & 141.0 & 68.0 & 71.5 & 61.8 \\
\hline Ce & 227.4 & 171.1 & 17.5 & 204.5 & 117.4 & 81.2 & 128.0 & 115.3 & 251.9 & 120.3 & 132.5 & 132.4 \\
\hline Pr & 28.7 & 21.3 & 2.1 & 25.7 & 15.0 & 8.7 & 12.6 & 13.2 & 27.7 & 12.6 & 14.0 & 16.5 \\
\hline Nd & 104.0 & 75.3 & 7.4 & 97.0 & 58.3 & 30.1 & 38.8 & 47.2 & 96.8 & 41.9 & 48.1 & 62.8 \\
\hline $\mathrm{Sm}$ & 17.8 & 1.6 & 0.9 & 20.5 & 12.7 & 5.5 & 5.2 & 7.2 & 15.6 & 7.3 & 9.2 & 13.9 \\
\hline Eu & 2.5 & 2.1 & 0.2 & 1.7 & 1.7 & 1.2 & 1.3 & 2.8 & 3.2 & 1.1 & 1.4 & 1.6 \\
\hline Gd & 17.7 & 9.0 & 0.8 & 21.7 & 12.6 & 5.7 & 5.1 & 6.5 & 15.5 & 7.3 & 9.5 & 14.4 \\
\hline $\mathbf{T b}$ & 2.5 & 0.9 & 0.1 & 3.5 & 2.0 & 0.8 & 0.5 & 0.7 & 1.8 & 0.9 & 1.5 & 2.3 \\
\hline Dy & 25.9 & 6.0 & 0.7 & 37.4 & 19.9 & 7.5 & 4.0 & 4.9 & 15.8 & 8.0 & 15.2 & 24.7 \\
\hline Ho & 3.4 & 0.7 & 0.1 & 4.8 & 2.5 & 1.0 & 0.5 & 0.6 & 1.8 & 0.9 & 2.0 & 3.2 \\
\hline Hf & 1.8 & 1.4 & 0.9 & 8.0 & 2.3 & 6.5 & 5.3 & 3.0 & 8.4 & 5.7 & 6.2 & 7.6 \\
\hline $\mathbf{Y b}$ & 10.2 & 1.5 & 0.1 & 12.9 & 6.1 & 2.5 & 1.0 & 1.2 & 2.9 & 1.9 & 5.5 & 8.1 \\
\hline Lu & 15.8 & 2.4 & 0.2 & 20.3 & 9.5 & 4.0 & 1.6 & 1.9 & 4.2 & 2.9 & 8.8 & 12.4 \\
\hline $\mathrm{Ba} / \mathrm{Nb}$ & 5.07 & 5.60 & 7.23 & 11.00 & 6.25 & 14.52 & 360.33 & 153.52 & 214.68 & 76.00 & 60.56 & 56.27 \\
\hline $\mathbf{N b} / \mathbf{Y}$ & 0.34 & 1.76 & 12.17 & 0.10 & 0.72 & 0.81 & 0.15 & 0.57 & 0.16 & 0.32 & 0.14 & 0.09 \\
\hline $\mathbf{R b} / \mathbf{Y}$ & 0.33 & 4.09 & 33.62 & 0.14 & 0.52 & 1.66 & 7.38 & 6.74 & 2.21 & 5.04 & 1.86 & 0.65 \\
\hline $\mathbf{R b} / \mathrm{Sr}$ & 0.05 & 0.07 & 0.49 & 0.04 & 0.16 & 0.19 & 0.57 & 0.11 & 0.49 & 1.19 & 0.89 & 0.14 \\
\hline $\mathbf{L a} / \mathbf{Y b}$ & 9.43 & 48.82 & 49.64 & 7.05 & 8.40 & 17.87 & 76.21 & 51.71 & 49.31 & 35.98 & 13.01 & 7.61 \\
\hline$(\mathbf{L a} / \mathbf{Y b})_{\mathrm{N}}$ & 6.37 & 32.99 & 33.55 & 4.76 & 5.68 & 12.07 & 51.50 & 34.94 & 33.32 & 24.31 & 8.79 & 5.14 \\
\hline$(\mathrm{La} / \mathrm{Sm})_{\mathrm{N}}$ & 3.42 & 29.20 & 4.65 & 2.79 & 2.55 & 5.11 & 8.93 & 5.41 & 5.69 & 5.87 & 4.87 & 2.80 \\
\hline$(G d / L u)_{N}$ & 0.14 & 0.47 & 0.44 & 0.13 & 0.17 & 0.18 & 0.40 & 0.43 & 0.45 & 0.32 & 0.13 & 0.14 \\
\hline $\mathbf{E u} / \mathbf{E} \mathbf{u}^{*}$ & 0.43 & 1.35 & 0.62 & 0.24 & 0.40 & 0.67 & 0.77 & 1.22 & 0.62 & 0.46 & 0.45 & 0.34 \\
\hline$(\mathrm{Nb} / \mathrm{U}) \mathbf{N}$ & 0.5053 & 0.3771 & 0.5704 & 0.1893 & 1.0488 & 0.5362 & 0.1116 & 0.3052 & 0.2177 & 0.2835 & 0.0838 & 0.2606 \\
\hline
\end{tabular}




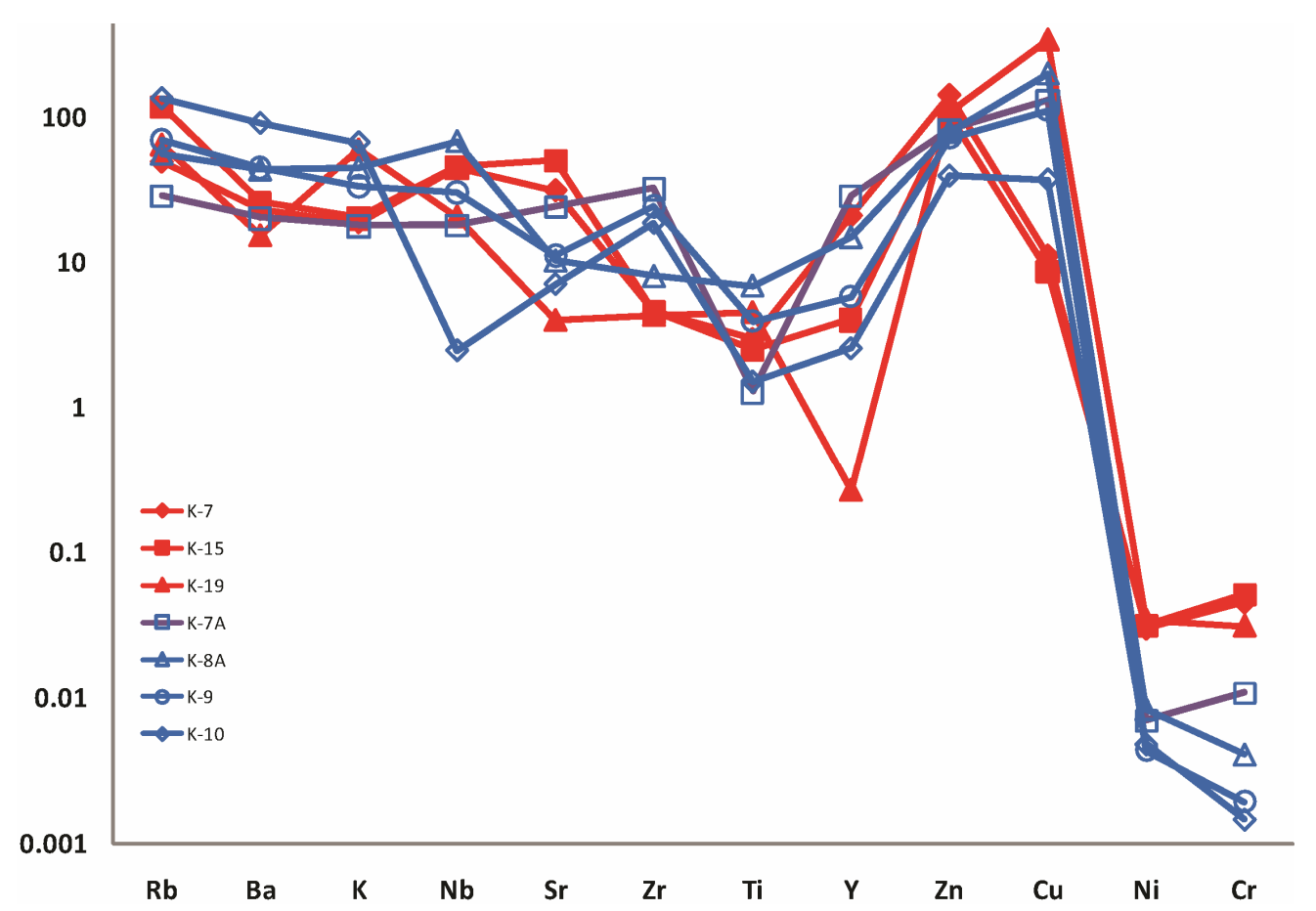

Figure 13. Primitive Mantle normalized spider plot of the patchy charnockite and mafic granulite of the Kabbaldurga quarries: showing the complementary trace element distribution patterns between the charnockite and mafic granulite. Normalization values after Taylor and McLennan, 1995. Symbols: Charnockite: Open; Mafic granulite: Solid.

59, and 270 vs. 232 ppm respectively). Unlike the contiguous grey-gneiss and charnockite pairs of Stahle et al. (1987) [6], the analyzed samples of the gneiss and charnockite here are not contiguous and gneiss samples are of granitic composition. Trace element distribution between the gneiss and charnockite could be argued against any genetic link between them, either by open system dehydration reactions (Stahle et al., 1987) [6], or by dehydration partial melting (Figure 14). Both $\mathrm{Ba} \& \mathrm{Sr}$ enrichment and depletion in the charnockites relative to the gneisses (as against $\mathrm{Ba} \& \mathrm{Sr}$ enrichment reported by Stahle et al., 1987) [6] and enrichment in $\mathrm{Ti}$, Ni \& Cr, and highly variable $\mathrm{Y}$ in the charnockites relative to the gneisses, could not be explained by any open system dehydration reactions. From contiguous gneiss-charnockite sample, Friend and Nutman (1992) [7] also could not find consistent pattern of trace element distribution for the supposed open system dehydration reactions attendant to the gneiss to charnockite transformation. Depletion of incompatible elements $\mathrm{K}, \mathrm{Rb} \& \mathrm{Ba}$ and enrichment in $\mathrm{Ti}, \mathrm{Ni} \& \mathrm{Cr}$ in the charnockites relative to the gneisses are compelling evidence against a genetic link between them via partial melting.

\subsubsection{REE}

LREE enrichment and HREE depletion in the patchy charnockites, together with relatively lower HREE frac- tionation $\left((\mathrm{Gd} / \mathrm{Lu})_{\mathrm{N}}\right)$, between 0.14 and 0.40 than LREE fractionation $\left((\mathrm{La} / \mathrm{Sm})_{\mathrm{N}}\right)$, between 2.55 and 8.93 suggests melt-pyroxene coexistence. On the other hand REE fractionation patterns are remarkably similar in the patchy charnockites and gneisses; $\left((\mathrm{La} / \mathrm{Sm})_{\mathrm{N}}\right): 2.55-8.93$ and 2.8 - 5.87; $\left((\mathrm{Gd} / \mathrm{Lu})_{\mathrm{N}}\right): 0.13-0.40$ and $0.13-0.32$; and $\mathrm{Eu} / \mathrm{Eu}^{*}: 0.24-0.77$ and $0.34-0.46$ respectively. This also argues against a partial melting relation between the patchy charnockites and the gneisses of the Kabbaldurga quarries (Figure 15).The REE fractionation patterns in the patchy charnockites are also not significantly different from those in the mafic granulites of the Kabbaldurga quarries: $\left((\mathrm{La} / \mathrm{Yb})_{\mathrm{N}}\right), 4.76$ - 51.5 and 6.37 - 33.55 respectively; and $\left((\mathrm{Gd} / \mathrm{Lu})_{\mathrm{N}}\right), 0.13-0.40$ and $0.14-0.47$ respectively, although, LREE fractionation in the mafic granulites are more variable: $\left((\mathrm{La} / \mathrm{Sm})_{\mathrm{N}}\right), 3.42$ - 29.2 than those in the patchy charnockites: $2.55-8.93$. It is evident that on this ground alone, the melt to restite relation between the patchy charnockites and mafic granulites could not be postulated. However, the trace element distribution between the patchy charnockite and mafic granulite showing definite signatures of disequilibrium, can possibly explain the seemingly similar REE fractionation patterns in the two entities.

\section{ISOTOPIC CONSTRAINTS}

$\mathrm{Sm}-\mathrm{Nd}$ isotopic compositions of the twelve samples 


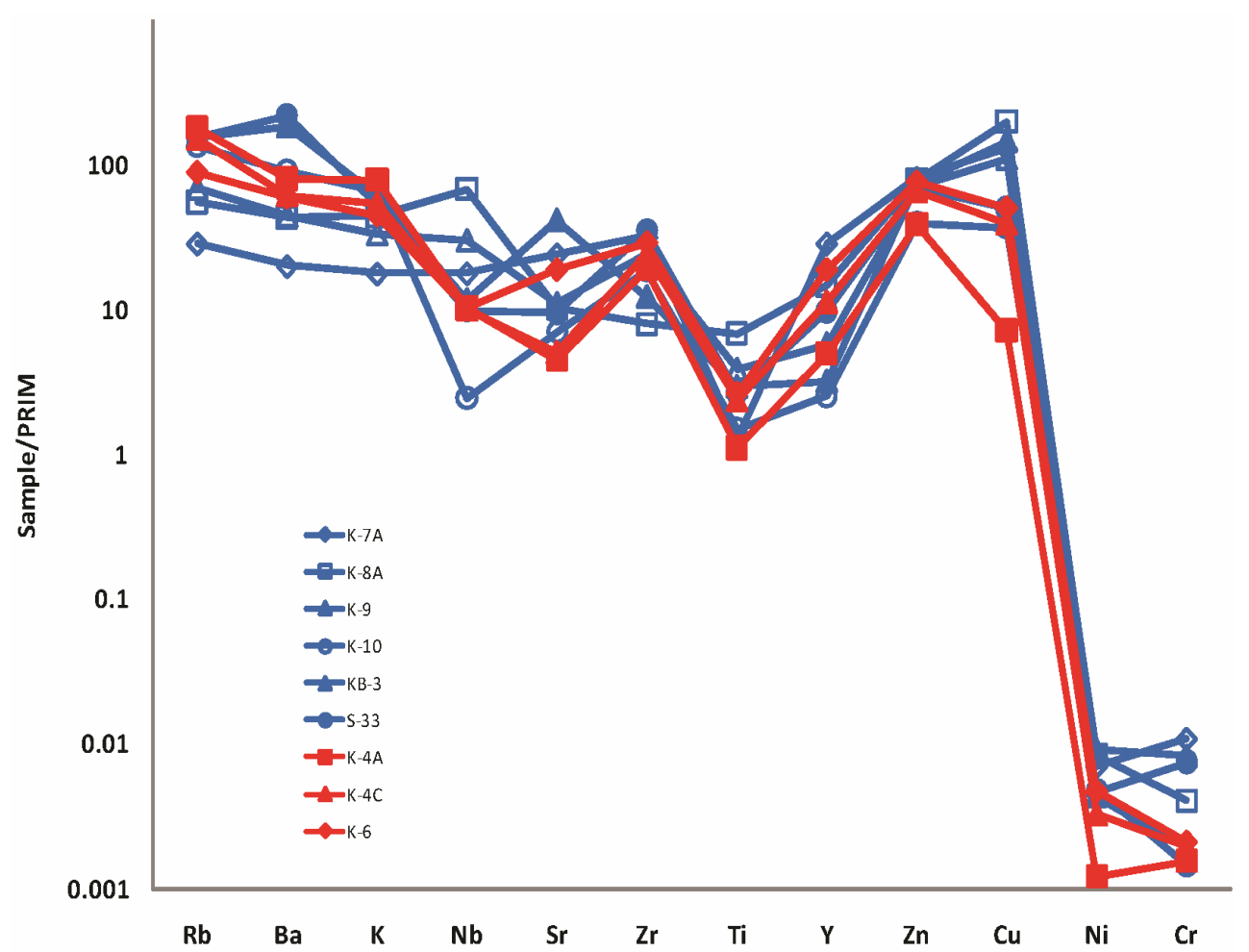

Figure 14. Primitive Mantle normalized spider plot of the patchy charnockite and peninsular gneisses of the Kabbaldurga quarries. Symbols: Charnockite: Open; Gneiss: Solid.

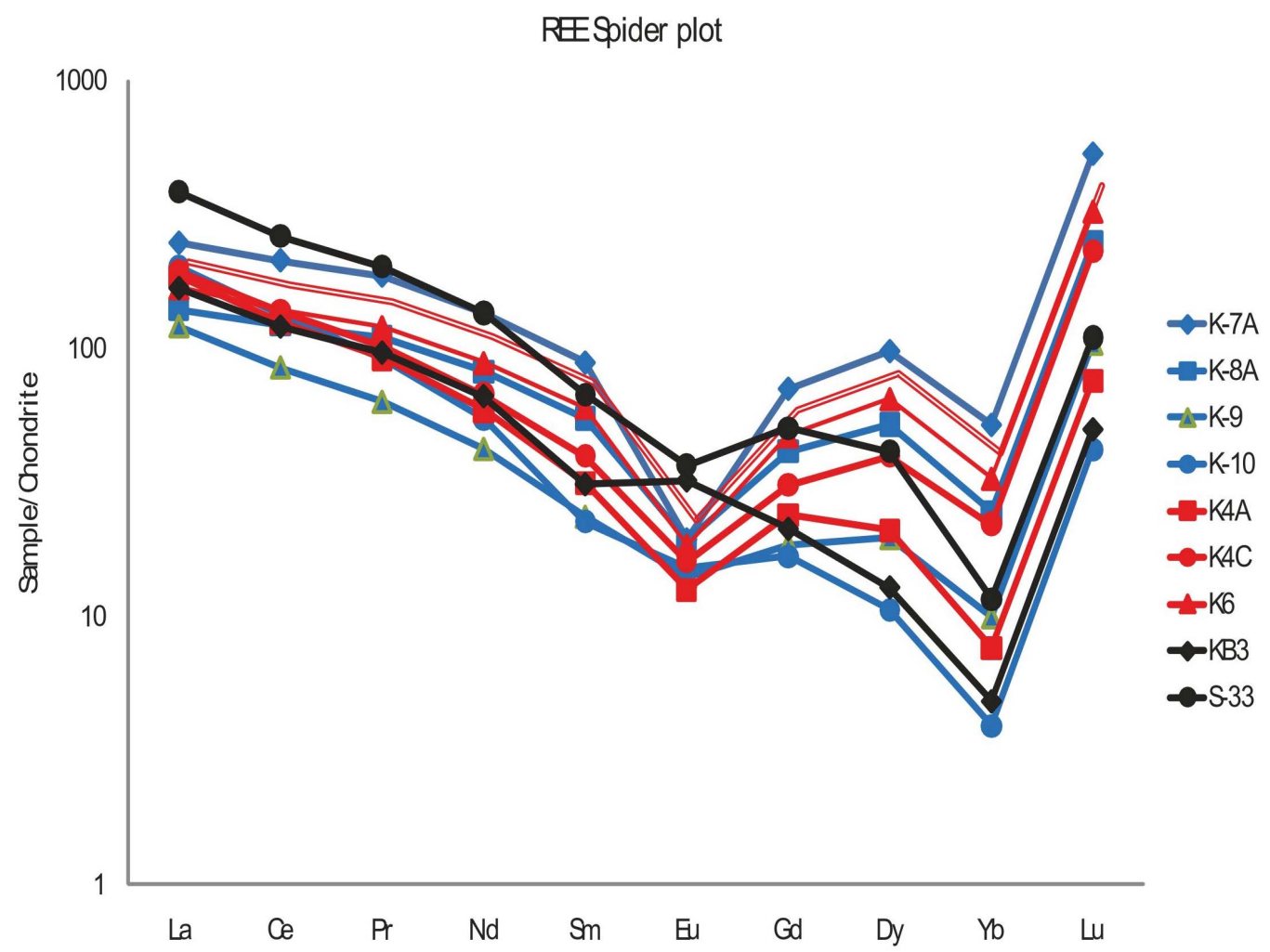

Figure 15. Chondrite normalized REE spider plot of the charnockite patches and gneisses at the Kabbaldurga quarries. Normalization values after Taylor and McLennan, 1995 [27]. Symbols: Charnockite: Open; Mafic granulite: Solid. 
have been determined to constrain the possible geochronological relation or otherwise between the gneiss and charnockite.

\section{Results}

The Sm-Nd isotopic compositions of the twelve samples are given in Table 2. The granulite suite of the Kabbaldurga quarries were isotopically monitored, however Sm-Nd whole rock data could not provide any meaningful isochron for the patchy charnockites or in combination with the mafic granulites. This could be explained by the chemical disequilibrium for certain trace elements, as manifest in the spider plot (Figure 13). It is also important to note that rehydration is quite common in the patchy charnockites (cf. Figures 12(b) and (c)). Thus it is evident that whole rock isotopic systems were disturbed during later retrogression/or cooling and even this did not completely rehomogenize the isotopic systems. Consequently, neither the granulite event nor the retrogression event could be dated by the whole rock isotopic systems. The only meaningful dates, that could be retrieved from the whole rock isotopic systems is the mantle derivation age of their protoliths, described by Ndmodel dates. The average Nd-model dates, or the crustal residence age of the four patchy charnockites and three mafic granulites is given as $3.08 \pm 0.08 \mathrm{Ga}$ and ${ }^{\varepsilon}$ values between 1.38 and 2.25 at $3.08 \mathrm{Ga}$. Incidentally, this model age is identical to that of a massive charnockite from the Karnataka craton described by Harris et al. (1994) [21]. The small positive ${ }^{\varepsilon}$ values further indicate juvenile crust formation at that time. The protoliths of the Peninsular gneiss of the Kabbaldurga indicate similar crustal residence age of $3.17 \pm 0.24 \mathrm{Ga}$, with ${ }^{\varepsilon}$ values between 1.29 and 2.19; while those of the massive charnockites indicate $3.1 \mathrm{Ga}$ with ${ }^{\varepsilon}$ values between 0.43 and 2.07 .

\section{DISCUSSION}

\subsection{Patchy Charnockite as Melt}

The critical field features, such as charnockite patches across gneissosity of the Peninsular gneiss and also as branching veins would indicate movement away from the source and hence rather than in situ transformation, an anatectic melt origin could be the favored interpretation. Some of the charnockitic patches in shear bands and fold noses may represent channel ways for fluid ingress as envisioned by earlier workers (Stahle et al. 1987) [6] and fluid-inclusion studies from several localities of South India, except Kabbaldurga (Ravindra Kumar and Venkatesh Raghavan, 1992, Srikantappa et al., 1992, Santosh and Tsunogae, 2003) [11-13] favored in situ transformation triggered by $\mathrm{CO}_{2}$-fluid ingress. But in view of the many diversely oriented and branching charnockitic veins transecting gneissic foliation in Kabbaldurga quarries, our favored interpretation would be emplacement of anatectic melt in some structural weak zones. On the other hand, a close genetic link between mafic granulite and charnockite is indicated by occurrence of charnockitic leucosomes at the margins of mafic granulite bodies as also

Table 2. Sm-Nd isotopic composition of the different assemblages in the Kabbaldurga quarries.

\begin{tabular}{|c|c|c|c|c|c|c|c|}
\hline \multicolumn{8}{|c|}{ Patchy charnockite } \\
\hline Sample & $\mathrm{Sm}(\mathrm{ppm})$ & $\mathrm{Nd}(\mathrm{ppm})$ & ${ }^{147} \mathrm{Sm} /{ }^{144} \mathrm{Nd}$ & ${ }^{143} \mathrm{Nd} /{ }^{144} \mathrm{Nd}$ & ${ }^{\varepsilon}(0)$ & $\mathrm{T}_{\mathrm{DM}} \mathrm{Ga}$ & ${ }^{\varepsilon}\left(\mathrm{T}_{\mathrm{DM}}\right)$ \\
\hline $\mathrm{K}-7 \mathrm{~A}$ & 18.096 & 90.949 & 0.1203 & 0.511209 & -27.88 & 3.12 & 1.69 \\
\hline $\mathrm{K}-8 \mathrm{~A}$ & 9.683 & 45.886 & 0.1276 & 0.51124 & -27.27 & 3.32 & 1.38 \\
\hline K-9 & 4.431 & 25.064 & 0.1069 & 0.51085 & -34.88 & 3.23 & 1.48 \\
\hline $\mathrm{K}-10$ & 4.652 & 32.819 & 0.0857 & 0.510468 & -42.34 & 3.15 & 1.58 \\
\hline \multicolumn{8}{|c|}{ Massive charnockite } \\
\hline KB-3 & 5.976 & 39.033 & 0.0926 & 0.510848 & -34.93 & 2.86 & 2.07 \\
\hline S-33 & 5.717 & 35.107 & 0.0984 & 0.510058 & -40.14 & 3.34 & 0.43 \\
\hline \multicolumn{8}{|c|}{ Mafic granulite } \\
\hline $\mathrm{K}-7$ & 18.174 & 104.796 & 0.1048 & 0.510981 & -32.32 & 3 & 1.86 \\
\hline $\mathrm{K}-15$ & 11.313 & 85.626 & 0.0799 & 0.51071 & -37.62 & 2.75 & 2.25 \\
\hline K-19 & 14.618 & 80.451 & 0.1098 & 0.511103 & -29.95 & 2.96 & 1.93 \\
\hline \multicolumn{8}{|c|}{ Peninsular gneiss } \\
\hline $\mathrm{K}-4 \mathrm{~A}$ & 6.072 & 35.007 & 0.1049 & 0.510715 & -37.51 & 3.36 & 1.29 \\
\hline $\mathrm{K}-4 \mathrm{C}$ & 5.801 & 29.778 & 0.1178 & 0.511014 & -31.68 & 3.34 & 1.34 \\
\hline K-6 & 11.484 & 56.343 & 0.1232 & 0.511447 & -23.23 & 2.83 & 2.19 \\
\hline
\end{tabular}


by charnockitic veins within some mafic granulite enclaves. Complementary trace element distribution between mafic granulite enclaves and branching veins of charnockite is consistent with a genetic link between them via dehydration partial melting. At this point we would like to emphasize that the relation between the patchy charnockites and mafic granulites have not been explained in the hypothesis of incipient growth by $\mathrm{CO}_{2}$ fluid ingress. While in situ transformation by fluid ingress does not uniquely explain all the charnockite patches in Kabbaldurga and its neighborhood, dehydration melting in mafic rocks is capable to do that, as various stages of segregation and mobility in a migmatite terrain. In some instances deformation enhanced the small volume melts to move short distances and segregate as anatectic melts in shear bands and fold noses within the host gneiss. Sawyer (1991) [22] described similar features, and indicated that anatectic melts were collected in dilatational structures, thought to be driven by pressure gradients developed during synanatexis non-coaxial deformation. It is important to note that disequilibrium chemical compositions in such charnockitic patches (described in a previous section) is also consistent with rapid segregation as envisioned by Sawyer (1991) [22]. On the other hand, veins and leucosomes at mafic granulite margins could represent the early predeformation stage, when unaided by deformation the small volume melt could not escape the source. This is also consistent with the restitic nature of the mafic granulites.

\subsection{Validity of the Transition Zone}

Although some workers have related the "incipient" charnockite and large-scale charnockite by the hypothesis of progressive charnockitization (Srikantappa et al., 1985) [23], Raith and Srikantappa (1993) [24] argued "on the evidence of field relations, petrological, geochemical and isotopic data, that development of arrested charnockites is a late-stage phenomenon; and regionalscale granulites could have been generated by dehydration melting processes". Moreover, from a structural point of view Naha et al. (1993) [15] indicated two types or phases of charnockite formation, separate in time and process. The pre-existing deep crustal granulites at Kabbaldurga quarries was indicated as the source of the $\mathrm{CO}_{2}{ }^{-}$ fluid, said to be responsible for the gneiss to incipient charnockite transformation (Raith et al., 1988) [17]. And exposed mafic granulite enclaves in the Kabbaldurga quarries described here and by Bhattacharya and Sen (2000) [18] further confirms an older granulite event to those represented by the patchy charnockites of Kabbaldurga and its neighborhood.

Although, Mojzsis et al. (2003) [16] could not find evidence of an older (Mid-Archean) metamorphic event, and argued for the profound granulite event at $2.53-2.51$
$\mathrm{Ga}$, several workers have reported granulite event around $2.9 \mathrm{Ga}: \mathrm{Rb}-\mathrm{Sr}$ whole rock isochron age of $2845 \mathrm{Ma}$ from Haluguru charnockite (Devaraju and Laajoki, 1986) [25]; and $\mathrm{Rb}$-Sr whole rock isochron age of $2.9 \mathrm{Ga}$ from massive charnockites of Kollamalai and Pachchaimalai hills (Choudhary et al., 2011) [26].

Although our whole rock data could not provide any meaningful age for the granulite event at Kabbaldurga, yet the migmatitic nature of the Peninsular gneisses at Kabbaldurga and disposition of the charnockitic veins and patches (interpreted as melt) across the gneissosity clearly indicate a later granulite cum crustal anatectic event, that could represent the erstwhile reported $2.5 \mathrm{Ga}$ granulite event.

Thus, even the incipient charnockite hypothesis evidently relates to a later event relative to the massive granulites of the Dharwar craton and hence the conception of a transition zone needs to be revised.

\subsection{Widespread Mafic Magmatism in South India}

The mafic magmatic source rocks of the Kabbaldurga granulite suite, with average crustal residence age of 3.08 Ga and small positive ${ }^{\varepsilon}$ values indicate the juvenile crust formation in this terrain. Incidentally, Harris et al. (1994) [21] described identical protolith age for a massive charnockite from the Karnataka craton. Friend and Nutman (1992) [7] interpreted U-Pb zircon age of $2965 \pm 4 \mathrm{Ma}$ as the protolith age of Peninsular gneiss at Kabbaldurga, and this is not much different from that described here. Chaudhary et al. (2011) [26] also described two massive charnockites from South India and isotopic considerations suggest a short crustal residence time for the basaltic protolith prior to melting (under granulite facies conditions, indicated by Rb-Sr isochrons, 2931 and $2902 \mathrm{Ma}$ ) with mantle-like ${ }^{87} \mathrm{Sr} /{ }^{86} \mathrm{Sr}$ and ${ }^{143} \mathrm{Nd} /{ }^{144} \mathrm{Nd}$ isotopic ratios and positive epsilon values for most of the samples, and hence SGT massives could be ascribed to growth of new continental crust around $2.98 \mathrm{Ga}\left(\mathrm{T}_{\mathrm{DM}}\right)$. This and the virtually identical crustal residence ages of the granulite suite and the Peninsular gneiss at Kabbaldurga, along with those reported by Harris et al. (1994) [21] for the source of massive charnockite demonstrate a wide spread mafic magmatic event around 3.0 Ga.

\section{CONCLUDING REMARKS}

1) All the patchy charnockites of Kabbaldurga are not amenable to explanation by in situ transformation from amphibolite facies gneisses.

2) Particularly, the charnockitic leucosomes at mafic granulite margins and charnockitic veins within mafic granulite enclaves are akin to dehydration partial melting in mafic rocks, and this is further corroborated by com- 
plementary trace element distribution between them.

3) Mafic granulite enclaves, representing older granulite event relative to the patchy charnockites of Kabbaldurga strongly argue against the notion of a transition zone.

4) The earliest and juvenile crust formation at Kabbaldurga at $\geq 3.0 \mathrm{Ga}$, is identical with that reported for massive granulites/charnockites, signifying a widespread mafic magmatism in South India around 3.0 Ga.

\section{ACKNOWLEDGEMENTS}

The Indian Statistical Institute, Kolkata, provided the infrastructural facilities. Isotopic work was carried out at the DST sponsored National Facility for Isotope Geology and Geochronology at IIT Roorkee. ICP-MS facility for trace element analysis was provided by IIT Roorkee. Thanks are due to Ms Poornima Saini and Shri Kamal Singh Gotyan for sample preparation and running the ICP-MS.

\section{REFERENCES}

[1] Pichamuthu, C.S. (1960) Charnockite in the making. $\mathrm{Na}-$ ture, 188, 135-136. doi:10.1038/188135a 0

[2] Newton, R.C., Smith, J.V. and Windley, B.E. (1980) Carbonic metamorphism, granulites and crustal growth. Nature, 288, 45-50. doi:10.1038/288045a 0

[3] Janardhan, A.S., Newton, R.C. and Hansen, E.C. (1982) The transformation of amphibolites facies gneiss to charnockite in Southern Karnataka and Northern Tamilnadu, India. Contributions to Mineralogy and Petrology, 79, 130-149. doi:10.1007/BF01132883

[4] Friend, C.R.L. (1985) Evidence for fluid pathways through Archean crust and the generation of the Closepet granite, Karnataka, South India. Precambrian Research, 27, 239250. doi:10.1016/0301-9268(85)90014-2

[5] Hansen, E.C., Janardhan, A.S., Newton, R.C., Prame, W.K.B.N. and Ravindra Kumar, G.R. (1987) Arrested charnockite formation in Southern India and Sri Lanka. Contributions to Mineralogy and Petrology, 96, 225-244. doi:10.1007/BF00375236

[6] Stahle, H.J., Raith, M., Hoernes, S. and Delfs, A. (1987) Element mobility during incipient granulite formation at Kabbaldurga, Southern India. Journal of Petrology, 28, 803-834. doi:10.1093/petrology/28.5.803

[7] Friend, C.R.L. and Nutman, A.P. (1992) Response of zircon $\mathrm{U}-\mathrm{Pb}$ isotopes and whole-rock geochemistry to $\mathrm{CO}_{2}$ fluid-induced granulite-facies metamorphism, Kabbaldurga Karnataka, South India. Contributions to Mineralogy and Petrology, 111, 299-310. doi:10.1007/BF00311193

[8] Brown, M. (1994) The generation, segregation, ascent and emplacement of granite magma: The migmatite-tocrustally-derived granite connection in thickened orogens. Earth-Science Review, 36, 83-130. doi:10.1016/0012-8252(94)90009-4

[9] Peterson, J.W. and Newton, R.C. (1989). $\mathrm{CO}_{2}$-enhanced melting of biotite-bearing rocks at deep-crustal pressure- temperature conditions. Nature, 340, 378-380. doi: $10.1038 / 340378 \mathrm{a} 0$

[10] Hansen, E.C., Newton, R.C., Janardhan, A.S. and Lindenberg, S. (1995) Differentiation of Late Archean crust in the Eastern Dharwar craton, Krishnagiri-Salem area, South India. Journal of Geology, 103, 629-651. doi:10.1086/629785

[11] Kumar, G.R.R. and Raghavan, V. (1992) Incipient charnockites in transition zone, khondalite zone and granulite zone of South India: Controlling factors and contrasting mechanisms. Journal Geological Society of India, 39, 293-302.

[12] Srikantappa, C., Raith, M. and Touret, J.L.R. (1992) Synmetamorphic high density carbonic fluids in the lower crust: Evidence from the Nilgiri granulites, South India. Journal of Petrology, 33, 733-760. doi:10.1093/petrology/33.4.733

[13] Santosh, M. and Tsunogae, T. (2003) Extremely high density pure $\mathrm{CO}_{2}$ fluid inclusions in a garnet granulite from Southern India. Journal of Geology, 111, 1-16. doi: $10.1086 / 344578$

[14] Santosh, M., Tsunogae, T., Chayama, H., Sato, K., Li, J.H. and Liu, S.J. (2008) Carbonic metamorphism at ultrahightemperatures: Evidence from North China Craton. Earth and Planetary Science Letters, 266, 149-165. doi:10.1016/j.epsl.2007.10.058

[15] Naha, K., Srinivasan, R. and Jayaram, S. (1993) Structural relations of charnockites of the Archaean Dharwar craton, southern India. Journal of Metamorphic Geology, 11, 889-895. doi:10.1111/j.1525-1314.1993.tb00198.x

[16] Mojzsis, S.J., Devaraju, T.C. and Newton, R.C. (2003) Ion Microprobe $\mathrm{U}-\mathrm{Pb}$ age determination on zircon from the Late Archean granulite facies transition zone of Southern India. Journal of Geology, 111, 407-425. doi:10.1086/375285

[17] Raith, M., Stahle, H.J. and Hoernes, S. (1988) Kabbaldurga-type charnockitization: A local phenomenon in the granulite to amphibolites grade transition zone. Journal of the Geological Society of India, 31, 116-117.

[18] Bhattacharya, S. and Sen, S.K. (2000) New insights into the origin of Kabbaldurga charnockites, Karnataka, South India. Gondwana Research, 3, 489-506. doi:10.1016/S1342-937X(05)70756-5

[19] Gopalakrishna, D., Hansen, E.C., Janardhan, A.S. and Newton, R.C. (1986). The southern high-grade margin of the Dharwar Craton. Journal of Geology, 94, 247-260. doi:10.1086/629026

[20] Bhattacharya, S, Chaudhary, A.K., Saw, A.K. and Das, P. (2011) Mafic granulite xenoliths from the East Indian Shield: Evidence for recycled continental crust in the Archean mantle. Lithosphere, 3, 155-169. doi:10.1130/L120.1

[21] Harris, N.B.W., Santosh, M. and Taylor, P.N. (1994) Crustal evolution in South India: Constraints from $\mathrm{Nd}$ isotopes. Journal of Geology, 102, 139-150. doi:10.1086/629659

[22] Sawyer, E.W. (1991). Disequilibrium melting and the rate of melt-residuum separation during migmatization of ma- 
fic rocks from the Grenville Front Quebec. Journal of Petrology, 32, 701-738. doi:10.1093/petrology/32.4.701

[23] Srikantappa, C., Raith, M. and Spiering, B. (1985) Progressive charnockitization of a leptynite-khondalite suite in southern Kerala, India: Evidence for formation of charnockites through a decrease in fluid pressure? Journal of Geological Society of India, 26, 62-83.

[24] Raith, M. and Srikantappa, C. (1993) Arrested charnockite formation at Kottavattam, Southern India. Journal of Metamorphic Geology, 11, 815-832. doi:10.1111/j.1525-1314.1993.tb00192.x

[25] Devaraju, T.C. and Laajoki, K. (1986) Mineralogy and mineral chemistry of the manganese-poor and manganif- erous iron-formations from the high-grade metamorphic terrain of Southern Karnataka, India. Journal Geological Society of India, 28, 134-164.

[26] Choudhary, A.K., Jain, A.K., Singh, Sandip, Manickavasagam and R.M., Chandra, K. (2011) Crustal accretion and metamorphism of Mesoarchean granulites in PalghatCauvery shear zone, Southern India. Journal Geological Society of India, 77, 227-238. doi:10.1007/s12594-011-0029-0

[27] Taylor, S.R. and McLennan, S.M. (1995) The geochemical evolution of the continental crust. Review Geophysics, 33, 241-265. doi:10.1029/95RG00262 